\title{
EL ARTE DE USURPAR. SEÑORES, MORISCOS Y CRISTIANOS VIEJOS EN EL MARQUESADO DE LOS VÉLEZ,
} 1567-1568

\author{
Francisco Andujar Castillo* \\ Manuel Barrios Aguilera**
}

Corría el mes de abril (acaso mayo, pues la fecha no se ha reseñado con exactitud) de 1567 cuando García Ramí, procurador morisco de Vélez Blanco, es apresado y conducido a la cárcel de Las Cuevas por una deuda que, en nombre de los cristianos nuevos de su villa, mantenía con un solicitador de pleitos de Granada. En agosto, el preso "es acercado" a la cárcel de Vélez Blanco para que sus hermanos de fe presencien su puesta en libertad. Previamente dos moriscos, Rodrigo Cehel y Rodrigo Almorid, han pagado la respetable suma de seiscientos ducados para saldar la deuda de Ramí.

El 8 de junio de ese mismo año, domingo, un cristiano viejo de Vélez Blanco, Francisco Barriga, dando grandes voces se había presentado en la casa del alcalde mayor de Lorca, donde se encontraban reunidos los delegados de don Luis Fajardo, marqués de los Vélez, con los representantes del concejo y de la comunidad morisca de Vélez Blanco, so capa de defensa de los intereses de los procuradores moriscos, arguyendo airadamente que estaban allí por la fuerza y engañados.

Lo relatado en estas dos pinceladas es el principo del fin de una historia compleja, plagada de contradicciones y paradojas ${ }^{1}$. Una historia, que si en

* Universidad de Almería.

** Universidad de Granada.

1. Las informaciones documentales sobre las que construimos el relato de los hechos proceden sobre todo de las comparecencias notariales de las partes implicadas para designar representantes, otorgar poderes, ratificar acuerdos, etc., recogidas en los correspondientes protocolos conservados en el Archivo Histórico Municipal de Lorca (AHML); así como de 
una consideración inmediata y elemental suscita algunas preguntas obvias - ¿por qué un cristiano viejo sale en defensa de los moriscos?; ¿qué se trama en Lorca?; ¿quién había pagado para liberar a Ramí?-, se convierte en un auténtico mar de interrogantes cuando se trata de elucidar el sentido profundo de una relación conflictiva -pues ésta no es sino la historia de un conflicto-, que hunde necesariamente sus raíces muy atrás, y que, si en este punto se nos aparece especialmente exasperada en su desarrollo, sólo es explicable en la relación tradicionalmente problemática, desde los mismos tiempos de la conquista, entre las partes implicadas: señor, comunidad morisca y comunidad viejo-cristiana.

Sin entrar en otras consideraciones de carácter metodológico ${ }^{2}$, que, además de distraer la atención de un relato denso en alternativas, haría excesivamente extensa esta aportación primera, hemos de remontarnos a varias décadas atrás, cuando don Luis Fajardo, segundo marqués de los Vélez, sucede a su padre, don Pedro ${ }^{3}$.

las sentencias dictadas por Ia justicia de la Chancillería de Granada sobre los pleitos que mantuvieron en los años previos a la concordia que nuclea el relato, que se guardan en el Archivo de la Real Chancillería de Granada (ARChG). Por fortuna, los hechos han dejado su huella en la documentación de la casa señorial de los Vélez, integrada hoy en el Archivo Ducal de Medina Sidonia (ADMS), en valiosos testimonios que se centran en la "transacción y concordia" que tanto ocupó al segundo marqués de los Vélez. Por último, en el Archivo Histórico Provincial de Almería (AHPA) hemos podido atar algún cabo suelto de una historia de la que nunca sabremos toda la verdad y documentar ésta o aquella circunstancia, siempre significativa, de alguno de los personajes implicados.

2. Bástenos al respecto la remisión -a modo de excusa, pero también de liberación de mayores precisiones- a una obra excepcional, J. CoNTRERAs, Sotos contra Riquelmes. Regidores, inquisidores y criptojudios (Madrid, 1992), que, servata distantia, pregonamos, gustosamente, como paradigma de esta pequeña aportación nuestra, por un doble motivo: primero, por cuanto metodológicamente es la demostración palpable de que el buen relato no está reñido con la mejor trađición científica y académica, y que el enfoque microhistórico puede dar frutos enormemente ricos, sobre todo si se cuenta con la alta preparación técnica del autor y con unas fuentes especialmente ricas como las que venturosamente hallo; segundo, por el azar de la concomitancia geográfica (esta historia también se desarrolla en parte en la ciudad de Lorca, del Reino de Murcia, pero tan vinculada espacial e históricamente al de Granada y, más particularmente, al Marquesado de los Vélez, aunque sea la villa señorial de Vélez Blanco la que centre el desarrollo de los hechos) e, incluso, cronológica, bien que los componentes son muy diversos.

3. Entre los años 1492 y 1516, los Fajardo lograron establecer una base firme en Almería, "si no muy rica sí lo suficiente cercana a sus posesiones en el reino de Murcia para que formaran entre todas ellas un señorío ciertamente sólido y geográficamente muy bien definido" (A. Franco), con cabeza en la que fue la villa señorial, Vélez Blanco, presidida por su impresionante castillo. Además de esta villa, formaban el señorío: Vélez Rubio, María, Oria, Cantoria, Partaloa, Albox, Arbolea, Albanchez, Benitagla, Las Cuevas y La Portilla. Con todas estas localidades, es comprensible que la bibliografía generada, dentro o fuera del ámbito académico, sea numerosa, mayormente las pequeñas monografías, que han encontrado en las publicaciones periódicas locales Roel. Cuademos de civilización de la Cuenca del Almanzora y Reoista Velezana acogida preferente. Así pues, en la presente nota, nos limitaremos a presentar una selección de aquellos trabajos que por su mayor entidad u oportuni- 


\section{MORISCOS VERSUS SEÑOR}

La asunción del Marquesado por don Luis Fajardo se produce en el año 1546. Aunque se ignora el detalle de la relación del nuevo señor con sus súbditos moriscos se sabe que la conflictividad aumenta respecto de la etapa de

dad puedan servir al estudioso de base para seguir los avatares del señorío desde sus comienzos hasta el inicio mismo de la repoblación filipina, ya en los primeros años de la década de los setenta del siglo XVI, ante la imposibilidad de alargar más esta exposición. Dada la expresividad de los títulos, la disponemos en orden alfabético:

P. AlCAÍnA FERnÁnDEZ, Historia de la oilla de María. Una comunidad rural del Reino de Granada entre los siglos XV al XIX, Almería, 1992; M. Álvarez Rivas y T. Castro MartíneZ, «El Marquesado de los Vélez en el Archivo de la Real Chancillería de Granada. Siglo XVI», en Almería entre culturas (Siglos XIII-XVI), Almería, 1990, I, pp. 291-300; F. ANDÚJAR CASTILLO, «Entre la 'administración' y la esclavitud de los niños moriscos. Vélez Blanco (AImería), 1570-1580», en Mélanges Louis Cardaillac, Zaghouan, 1995, II, pp. 739-750; F. ANDúJAR CASTILlo, «La continuidad de la guerra de los moriscos: la esclavitud en los Vélez (15701590)», Teruel, en prensa; F. AndúJAR CASTILlo, «El Archivo Ducal de Medina Sidonia», Revista Velezana, 13, 1994, pp. 77-79; F. ANDÚJAR CASTILLO, «Los montes de los Vélez en el siglo XVI», en A. SÁNCHEZ PICON (ed.), Historia y medio ambiente en el territorio almeriense, AImería, 1996, pp. 83-97; F. ANDújar CASTILlo y M. BARRios AguILERA, «Los moriscos de los secanos. Mercedes de tierras a moriscos en el Marquesado de los Vélez (1551-1568)», en Actas del VII Simposio Internacional de Mudejarismo, Teruel, en prensa; F. ANDÚJAR CASTILLO, «Señores y Estado en la repoblación de Felipe II. El caso del marquesado de los Vélez», Chrónica Nova, en prensa; M. BARrios AgUiLERA, «Repoblación del valle del Almanzora después de la expulsión de los moriscos: Las Cuevas del Marquesado», Roel, 6, 1985, pp. 67-92; E. Ferre Bueno, El valle del Almanzora. Estudio geográfico, Almería, 1979; A. Franco SiLVA, «Datos demográficos y organización municipal de las villas almerienses de los Vélez (14921540)», Gades, 5, 1980, pp. 85-111; A. FRANCO SILVA, «La formación del señorío de los Vélez. Sus rentas y propiedades (1492-1540)», en Actas del I Coloquio de Historia de Andalucia. Andalucía Medieval, pp. 197-206, Córdoba, 1982; A. Franco SILvA, «Repartimientos de tierras en el obispado de Almería tras la expulsión de los moriscos (1570-1578)», Mélanges de la Casa de Velázquez, XIX-1, 1983, pp. 207-219; A. FrANCO SILvA, «El obispado de Almería tras su incorporación a la Corona de Castilla», Cuadernos de Estudios Medievales, VI-VII, 19781979, pp. 79-95; A. FRANCO SILVA, El Marquesado de los Vélez (siglos XIV-mediados del XVI), Murcia, 1995 (es en buena medida recopilación de los trabajos citados anteriormente, con alguno referido al señorío original murciano); J.A. GRIMA CERVANTES, «Las capitulaciones de 1488 y 1501 de la comarca de los Vélez», en Almería y el Reino de Granada en los inicios de la Modernidad (siglos XV-XVI), Almería, 1993, pp. 203-223; A.I. LLADO GRANADO, "La conservación de la superficie forestal en los Vélez (siglos XVI y XVII)», Revista Velezana, 9, 1990, pp. 5-12; G. MARAÑón, Los tres Vélez, en tomo VII de Obras completas, pp. 545-648, Madrid, 1982; C. MARTínez LÓPEZ (coord.), Vélez Blanco, nazarita y castellano, Granada, 1988; J.M. MARTíNEZ LÓPEz, "Conflicto en el apeo de Benitagla entre el marqués de los Vélez y el juez de comisión. Anotaciones al repartimiento», Almotacín, 2, julio-diciembre, 1983, pp. 33-45; F. PAlanques AYên, Historia de la villa de Vélez Rubio, antiguo Marquesado de los Vélez, desde los tiempos primitivos hasta nuestros días, Vélez Rubio, 1987 (ed. or., 1909); F. PALANQUES AYEN, Apuntes genealógicos y heraldicos de la villa de Vélez Rubio, Vélez Rubio, 1910; E. PÉrEz BOYERO, «La construcción de las iglesias en el Marquesado de los Vélez», en Actas del VI Simposio Internacional de Mudejarismo, Teruel, 1996, pp. 811-831; J. Rubio de la SERNA, Monografía de la villa de Vélez Rubio y su comarca, Barcelona, 1900; J.A. TAPIA GARRIDO, Vélez Blanco. La villa señorial de los Fajardo, Madrid, $1981^{2}$ (ed. or., 1959); J.A. TAPIA GARRIDO, «El señorío de los Fajardo en el Almanzora», Roel, 1, pp. 109-121; J.A. TAPIA GARRIDO, «La agricultura en el Almanzora durante la Baja Edad Media», Roel, 3, 1982, pp. 23-33; J.A. TAPIA 
su predecesor ${ }^{4}$, tal como acredita el incremento de pleitos y disputas diversas; los mismos moriscos de la villa de Vélez Blanco, cuando inician la negociación con el segundo marqués, reconocen que sus relaciones habían sido

GARRIDO, «Rebelión de los moriscos del Almanzora», Roel, 6, 1985, pp. 35-55; J.A. TAPIA GARRIDO, «Expulsión de los moriscos de los Vélez», Revista Velezana, 8, 1989, pp. 5-14; J.A. TAPIA GarRido, Historia General de Almería y su Provincia, Almería, 1981 ss. (1.5 tomos: interesan aquí especialmente los tomos IX, X y XI); B. VINCENT, «Un ejemplo de corso berberiscomorisco: el ataque de Cuevas de Almanzora, 1573», en Andalucía en La Edad Moderna: Economía y sociedad, Granada, 1985, pp. 287-301.

A la relación precedente, centrada en tierras o localidades del señorío de los Fajardo, deben de añadirse, al menos, dos libros muy recientes y abarcadores de la problemática señorial en el Reino de Granada, sobre la que arrojan nueva luz de comprensión, a la vez que abren perspectivas para estudios señoriales individualizados: E. SORIA MESA, Señores y oligarcas: los señorios del Reino de Granada en la Edad Moderna, Granada, 1997, y E. PEREZ BOYERO, Moriscos y cristianos en los señorios del Reino de Granada (1490-1568), Granada, 1997.

4. Es conocido el áspero enfrentamiento del primer marqués de los Vélez con el obispado de Almería a Io largo de muchos años por los diezmos, excusado y construcción de las iglesias de las villas del territorio señorial almeriense. Es muy probable que en este enfrentamiento haya que buscar las raices de una cierta "sobreprotección" -si se nos permite la expresión, manifiestamente excesiva seguramente, pues nunca pasó de la apariencia- del señor sobre sus vasallos moriscos ante un enemigo mayor. De ahí que se den episodios como el que sigue, que relatamos a modo de único ejemplo de entre otros: en carta, sin fecha, de don Pedro Fajardo a su solicitador de pleitos en la Chancillería, le pedía que intercediese ante la Inquisición de Granada por un morisco vasallo suyo de Las Cuevas, al que se creía en la obligación de proteger de las garras de su acérrimo enemigo, considerándolo uno "destos benditos mártires del obispo" (ADMS, Leg. 1289). Cualquier actividad inquisitorial contra los moriscos del Marquesado era interpretada por el marqués como obra de la "mano alargada" del obispo, en su intento de dañarlo a él. Cuando esto se produce, el marqués mueve sus resortes de intercesión ante el Santo Oficio, como cuando son acusados de degollar reses y se les prohíbe "que no hagan zanbras ni tomen sus pasatiempos" (Carta de don Pedro Fajardo a Diego de Quesada -su solicitador-, ADMS, Leg. 1298, sin fecha). Vid. A. FRANCO SILVA, «El obispado de Almería...», pp. 125-160; E. PEREZ BOYERO, «La construcción de las iglesias...».

Mas debe advertirse que el planteamiento del primer señor de los Vélez tuvo siempre

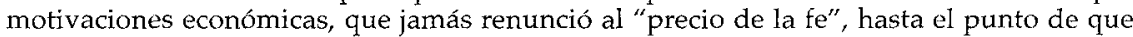
habría estado dispuesto a expulsar a los cristianos viejos con los que él mismo había repoblado si ello le supusiese un aumento de rentas: "Si justiçia no me vale y me desposeen desto, yo tengo aquí en esta villa dosyentos e çinquenta o tresyentos vasallos e hijos de vasallos moriscos que no tienen heredamientos, syno pocos, ni ganados, que se me ofreçen sus padres y otros que pagarán a los cristianos viejos que de aquí se fueren las casas, porque los dichos moriscos no las tienen en que bivir y biven en casa de sus padres con harta esterilidad, y que les pagarán asy mismo las viñas que plantaron en la tierra que yo les di por respeto de los diesmos que he dicho, y ay mismo les pagarán los ganados lanares y cabríos..." (Carta de don Pedro Fajardo a Morata, ADMS, Leg, 1298). Apretó, pues, cuanto pudo a sus vasallos, y no estuvo en modo alguno libre de conflictos y pleitos con ellos, aunque en desigual desarrollo espacial ( $c f$. M. Álvarez Rivas y T. CAStro Martinez, «EI Marquesado de los Vélez en el Archivo...», si bien fue en el término de María -mayoritariamente poblado por cristianos viejos, y donde el monte, con todo lo que implica, es elemento económico esencial- donde se observan episodios más enconados (por ejemplo, ADMS, Legs. 1298 y 532). Vid. F. Andújar CASTILLO, «Los montes de los Vélez...». 
mucho mejores con don Pedro Fajardo ${ }^{5}$. Se puede decir, incluso, que el relevo en la cabeza del señorío conlleva un cambio de rumbo cualitativo, que bien podría definirse con la frase "conflictividad antiseñorial". La razón fundamental es que el nuevo titular del señorío -aún no extintos los conflictos con la silla obispal almeriense, que habian caracterizado la etapa precedente, aunque sí atenuados- acentuará la presión económica sobre la comunidad morisca.

La misma documentación del acuerdo incluye un detallado itinerario por los caminos de las disputas entre moriscos y señor, objeto último de la concordia que pretendió acabar con tan dilatados pleitos. Pero de ella se desprende que lo que realmente sucedió es que los moriscos aprovecharon el cambio sucesorio en la casa nobiliaria para hacer frente a una serie de gravámenes, vejaciones, cargas y derechos abusivos que el primer marqués les había impuesto, con toda probabilidad a cambio de la protección "cultural". No en vano en junio de 1547, es decir, a los pocos meses de la muerte del primer marqués, los moriscos de Vélez Blanco entablan pleito, o lo que es lo mismo, piden "amparo de justicia" frente al poder señorial, ante la Chancillería de Granada, a causa de una amplia lista de agravios que, desde luego, habían sufrido por parte del primer Fajardo, pero que habían permanecido soterrados hasta ese momento.

La descripción de los abusos e imposiciones, aunque prolija, es ineludible, no sólo por su contenido mismo sino porque será imprescindible su cotejo con lo pactado entre ambas partes en 1567.

En primera instancia, estarían los abusos cometidos por los marqueses al aprovecharse, ya de sus bienes, ya de sus personas. Así denuncian que cada vez que el señor tenía que ir a la corte real o a cualquier otra parte tomaba las acémilas de los moriscos sin pagar por ello nada a cambio, ocasionando graves perjuicios a los campesinos que no las podían emplear en sus labranzas; que los obligaban a trabajar en los reparos de las casas y fortalezas de los marqueses sin percibir por ello salario alguno; que los utilizaban como mensajeros, en lugar de enviar a sus criados, pagando por ello la exigua cantidad de 25 maravedís por día; que eran obligados a aposentar en sus casas a los criados de los marqueses, circunstancia que éstos aprovechaban para poner en alquiler sus propias viviendas; que igualmente obligaban a los vecinos que vivían fuera de los adarves a cocer el pan en el "horno del marqués", a pesar de que en la villa había otros hornos particulares; que obligaban a los pastores a vender sus carneros a las personas que ordenaba el marqués. En el mismo sentido se encuentran otros abusos que recaían sobre los aprovechamientos de las tierras que trabajaban los moriscos, como apro-

5. AHML, Protocolos, 69. 
piarse de los alcaceres de los moriscos para los ganados y bestias de labor del señor, sin pagar por ello cosa alguna o pagándolos muy por debajo de su precio real, e impedirles que los ganados de los moriscos pacieran en sus propias rastrojeras.

Un segundo grupo de abusos se configuraba en torno a la imposición de tributos extraordinarios que, por supuesto, los moriscos consideraban como injustos. Así, sin derecho alguno según los moriscos, los marqueses se llevaban anualmente de cada vecino de la villa una carga de paja y leña de doce arrobas de peso, "y si faltava el dicho peso no se reçebían", y si algún vecino moría se le exigía su entrega a viudas y niños, "sin tener consideración a ser menores e pobres" 6 ; que estando encabezadas las alcabalas de la villa y su tierra, y estando obligados los vecinos a pagarlas a los arrendadores, los marqueses les hacían pagar la alcabala de las cosas que vendían, por lo que ante la duplicidad del pago, si dejaban de abonarlas a los arrendadores eran demandados por éstos. Igualmente, en relación con los pagos de impuestos, los vecinos moriscos denunciaban la obligación que les imponían de pagar los diezmos en la tercia del marqués, cuando la costumbre era que se abonasen en el mismo campo donde se cogían, tanto los diezmos de pan como del vino; semejante modificación en las fechas de pago les impusieron el cambiar el abono del diezmo de los ganados del día de san Pedro y san Pablo al día de san Miguel "para que tuviese más valor y estuviese más creçido el ganado".

Con todo, las quejas más importantes no son las expuestas hasta aquí, sino las referentes a las prohibiciones que limitaban sobremanera los derechos de los pobladores, tanto moriscos como cristianos viejos, de la explotación de la tierra y los montes públicos. La apropiación por parte de los marqueses de los términos públicos no cultivados, y por tanto del monte, constituyó el principal elemento de disputa y clave del pleito que los vecinos interpusieron. En otro lugar hemos descrito con detalle el proceso según el cual el primer marqués de los Vélez, desde la concesión del señorío en 1503, se autoproclamaba "propietario" de todas las tierras y montes de los términos de sus villas que no tuviesen propietario conocido o que no estuviesen puestas en explotación ${ }^{7}$. Este doble frente de propiedades se procuró definir por parte del Fajardo mediante la articulación de un marco jurídico que amparara estos derechos atribuidos. Así, los montes pronto tendrán una regulación a través de ordenanzas en las que claramente se define su acotamiento para distintos usos ${ }^{8}$. Las tierras no cultivadas, casi todas ellas ocupadas por monte bajo y alto, tendrán su propia ordenación reflejada en las mercedes de

6. AHML, Protocolos, 69, fol. $276 \mathrm{r}$.

7. F. Andújar Castillio y M. Barrios Aguilera, «Los moriscos de los secanos...».

8. F. Andújar CAstillo, «Los montes de los Vélez...», p. 89. 
tierras que se concederán precisamente a los moriscos a cambio del pago de una serie de contribuciones ${ }^{9}$.

Los moriscos denunciarán todas estas usurpaciones de derechos, traducidas en prohibiciones nuevas: "que de poco acá proybía y vedaba a los dichos vecinos que no pudiesen labrar en los términos ni romper de nuevo ni ensanchar sus labores so cierta pena", lo cual era considerado como un nuevo estanco y por tanto como un antiguo derecho de los vecinos; que siendo el término público y concejil para pasto y ejido de los ganados, el marqués lo había adehesado y acotado sin licencia real, imponiendo duras penas -tanto "lesivas corporales" como "pecuniarias" - contra quienes contravenían sus órdenes llevando a estas dehesas sus ganados ${ }^{10}$; por último, que no les permitía explotar los montes prohibiendo la corta de madera y de leña verde -entre otras cosas por preservar el monte para la afición cinegética del marqués-, aunque fuese para el aprovechamiento de sus casas y labores; limitación que se hacía extensiva, con un mismo fin, a no hacer fuegos fuera de los espacios cerrados ${ }^{11}$.

Los vecinos moriscos pusieron otra demanda a don Luis Fajardo sobre la organización del concejo, reclamando la potestad de nombrar los oficiales del mismo. Sobre este asunto, la Chancillería resolvió con celeridad en favor del marqués.

Sin embargo la justicia real no mostraría la misma rapidez en la resolución de los restantes asuntos sobre los que los vecinos habían demandado a don Luis Fajardo. Las influencias del marqués cerca de los jueces granadinos, merced a una larga experiencia en los litigios de su padre, tanto en Granada como en la corte, permitió que el pleito interpuesto se dilatara por años; tantos como que nunca sería sentenciado por completo.

En un primer momento, todas las acusaciones fueron rechazadas por el marqués con argumentos de todo signo, alegando entre otras cosas, bien que todos los derechos los tenía desde tiempo inmemorial, como era el caso de la facultad de conceder licencias para labrar nuevas tierras, bien que las ordenanzas -elaboradas por el propio marqués- fijaban las penas para la conservación de los montes. A modo de ejemplo: en el caso de la exigencia de llevar el pan al horno del marqués, tal imposición -en opinión del marqués- provenía de la obligación contraída por los vecinos que le habían pedido que lo construyese.

9. ADMS, Leg. 481: Libro de mercedes del Ilustrisimo Señor Marqués de los Vélez, Marqués de Molina, Adelantado Mayor y Capitán General del Reino de Murcia.

10. Los mismos vecinos estimaban que a causa de este adehesamiento del término se habían perdido unas 40.000 cabezas de ganado (AHML, Protocolos, 69, fol. $277 \mathrm{r}$ ).

11. F. ANDÚJAR CAstillo, «Los montes de los Vélez...», p. 92. 


\section{LA "JUSTICIA PARCIAL"}

La Chancillería de Granada se tomó largo tiempo para resolver el pleito, y cuando lo hizo, siempre procuró no otorgar una sentencia definitiva o completa. El modo de dilatar los asuntos, y de paso favorecer los intereses del demandado, era no emitir una sentencia sobre la totalidad del pleito, sino resolver sobre algunos de los asuntos contenidos en el mismo. El procedimiento jurídico consistía en repartir justicia de modo "parcial", sobre algunas demandas. En el fondo, esa justicia parcial era beneficiosa para los intereses del marqués -la parte verdaderamente gananciosa-, pues mientras tanto seguían vigentes los abusos y usurpaciones que perpetraba el señor sobre sus vasallos.

Una primera sentencia sobre el pleito se dictó, con carácter provisional, es decir, hasta que se produjera la resolución definitiva, en Granada, a 24 de septiembre de 1558. Se trata sin duda de una sentencia desfavorable a los intereses del marqués, pues lo obligaba a pagar cuando trabajasen los vasallos en sus obras, a abonar por las cargas de paja y leña que les tomaba cada año y a no percibir alcabala alguna adicional a la que ya recibía del encabezamiento. Estas resoluciones serían recurridas por don Luis Fajardo a fin de que quedaran igualmente suspensas, tal cual estaban las restantes peticiones de los vecinos.

Justo un año más tarde, el 23 de septiembre de 1559, la Chancillería emite un nuevo auto, una vez más "parcial", es decir, sin abordar la totalidad de los asuntos. Esta resolución será claramente favorable a las peticiones de los vecinos. La justicia falla en casi todos los puntos contra el marqués de los Vélez: que no les tome las bestias en contra de su voluntad; que no les obligue a hospedar criados del marqués por la fuerza, "a no ser que el marqués estuviese de camino, y tan sólo por dos o tres días"; que no les apremie a trabajar en las haciendas y obras del señor por la fuerza; y que no les obligue a hacer de mensajeros para servicio de la casa señorial. Más importancia aún tenía lo contenido en el auto relativo a los aprovechamientos del monte y los derechos de propiedad sobre las tierras no cultivadas. Sin duda éste es el gran revés para el marqués, que había iniciado una política de concesión de mercedes desde 1551, que se ve interrumpida a causa de esta resolución ${ }^{12}$. La sentencia reconoce la facultad de los vecinos para romper y ensanchar libremente tierras, así como beneficiarse de las rastrojeras de sus cultivos, aprovechar las dehesas para el pasto de sus ganados y cortar maderas y leñas de los montes. Por último, la sentencia reconocía a los vecinos libertad

12. El reflejo de esta sentencia se ve claramente en la evolución de las mercedes de tierras concedidas por Luis Fajardo desde 1551 a 1568. Vid. F. AndúJar Castillo y M. Barrios AGUILERA, «Los moriscos de los secanos...». 
plena en la venta de sus carneros sin que el marqués pudiese intervenir para nada en dicha venta. El único asunto que se resolvió en favor del marqués, en relación a la sentencia de 1558, fue la suspensión transitoria -una vez más hasta la resolución total del pleito- del derecho sobre las cargas de paja y leña que los vecinos debían entregarle anualmente.

En total, de catorce peticiones de justicia que los vecinos habían presentado, el auto de septiembre de 1559 les daba la razón en ocho, que, unidas a las dos también favorables de 1558, sumaban diez resoluciones en las que los vecinos ganaban la partida al marqués. Quedaban pendientes de dictamen por la justicia asuntos como el de la obligación de cocer el pan en el horno del marqués, las fechas y lugar de abono de los diezmos, los aprovechamientos de los sembrados y el ya citado sobre los derechos de paja y leña que estaba en suspenso. Hasta este punto, esta especie de "lucha antiseñorial", o más propiamente, la oposición a los abusos señoriales, había dado sus frutos.

Ante sentencia tan desfavorable, el marqués debió poner en marcha toda su amplia red clientelar y de influencias ante la justicia granadina. De inmediato trató de revocar el auto de 1559 alegando la reiterada idea de siempre sobre la que basaba todas sus argumentaciones: los derechos "desde tiempo inmemorial" -aun cuando tal tiempo apenas si superaba las cuatro décadas, pues en su origen se remontaba todo lo más al año 1503, en que los Fajardo reciben el señorío, alcanzando hasta 1547, en que comienzan estos pleitos-. De todas las resoluciones negativas, la que más perjudicaba a sus intereses era la que le negaba el derecho de propiedad sobre baldíos y montes, hasta el punto de que de ratificarse la sentencia sería como "quitarle el señorío" 13 .

Muy pronto el marqués consigue sus objetivos y logra que el auto de septiembre de 1559 sea revocado. Un nuevo auto dado en Granada el 4 de enero de 1560, deja en suspenso el de 1559, al declararlo nulo, y ordena el cumplimiento del auto de 1558. Los temas esenciales del pleito siguen sin resolución, y los vecinos sufren un serio revés en sus aspiraciones, a pesar de alguna nueva sentencia parcial como la dictada por la Chancillería el 12 de agosto de 1561.

Esta última tiene la apariencia de ser un tanto salomónica, es decir, trata de repartir justicia a partes iguales: los vecinos obtienen dictamen favorable en algunos puntos sobre los que ya habían recibido resolución en su favor en 1559 , los referentes a alojamientos de criados, aprovechamientos de alcaceres y venta de carneros. Son contrarios a los vecinos la obligación de contribuir con sus animales y hacer de mensajeros cuando el marqués se lo pidiese. Igualmente se resolvió en contra de los vecinos lo referente al aprovecha-

13. AHML, Protocolos, 69 , fol. 286 r. 
miento de los rastrojos y de la leña y madera de los montes, pues aun cuando se confirmaba a su favor la sentencia de 1559, al mismo tiempo se introducía como salvedad la obligación de ajustarse en estas materias a lo contenido en las ordenanzas que, en la práctica, coincidían con la posición del marqués. La resolución incluía copia de las ordenanzas de 15 de abril de 1541 que habían sido redactadas por las justicias del propio marqués en orden a "la conservación de los montes". Sin embargo, una vez más, lo más relevante de esta última sentencia era el reconocimiento implícito de los derechos señoriales sobre los baldíos, pues en este punto se revocaba sin más el auto de 1559 a pesar del ínterin solicitado por los vecinos. No era ciertamente una confirmación del derecho de propiedad sobre las tierras no cultivadas y montes, sino el reconocimiento de facto de los "derechos inmemoriales", siempre aducidos por el marqués.

Entre agosto de 1561 y enero de 1567 , la Chancillería de Granada no parece que emitiera nuevas sentencias parciales sobre tan complicado pleito. Las presiones del señor influirían sin duda tanto en la dilación de las sentencias como en los continuos vaivenes de las mismas.

\section{LA CONCORDIA DEL SEÑOR CON LOS MORISCOS}

\section{LOS ACTORES}

En el mes de enero de 1567 el interminable conflicto vuelve a resurgir. La Chancillería no resuelve. Las relaciones entre vecinos y señor debieron deteriorarse durante estos años. Lo cierto es que entre enero y junio de 1567 se entablan negociaciones entre ambas partes para tratar de llegar a un acuerdo. Que el asunto se retome en enero de 1567 nada tiene que ver con la puesta en práctica de la Pragmática que quebraba las relaciones moriscos/cristianos viejos y que conduciría finalmente a la rebelión de la Navidad de 1568.

Siendo este acuerdo -" pacto" o "concordia"- el tema nodal del trabajo, es obligado preguntarse de quién partió la iniciativa para llegar a él tras tantos años de conflictos y esperas de una justicia que nunca llegaba. Todo hace suponer que los demandantes, los vecinos, que habían padecido sentencias contrarias a sus intereses y que habían esperado muchos años para mejorar su situación, fuesen los interesados en llegar a un acuerdo con don Luis Fajardo que posibilitara al menos la aminoración de los agravios sufridos. Y en efecto, si damos crédito a la documentación judicial y notarial, en ella queda reflejado con meridiana claridad que los moriscos "están interesados en concertarse" y que han pedido al señor que nombre representantes para llegar a un acuerdo. Así se declara en una escritura otorgada el 26 de enero de 1567 ante el escribano de Vélez Blanco, Bartolomé Sánchez. Los moriscos solicitan el acuerdo en consideración a la "quietud de las conçiençias y la uti- 
lidad desta villa". Para ello, un grupo de notables moriscos, junto con los representantes del concejo, acuden a los "corredores de la fortaleza" para presentar la petición al marqués de los Vélez.

Es el comienzo de unos episodios que tienen mucho de representación teatral. La documentación misma que sustenta la información tiene todo el aspecto de ser una característica fuente "envenenada" 14 , esto es, tergiversadora de la realidad de los hechos. En contra de esas evidencias documentales, un análisis profundo de la cuestión nos dice que el verdadero mentor del inicio de las negociaciones, como del acuerdo final, será el propio marqués de los Vélez, don Luis Fajardo. Como testigos de esta escritura de 26 de enero figuran el licenciado Manchirón, regidor de Lorca, Alonso Rodríguez -futuro traidor a los intereses del marqués, como más adelante se verá-, Juan Bautista, portero de cámara del marqués, y su secretario Hernández Camacho. Desde esta fecha, todos ellos, con la salvedad del portero, serán protagonistas de excepción de los acontecimientos que tuvieron lugar en Vélez Blanco y Lorca. Siendo todos ellos "deudos" del marqués actuarán también como testigos de las escrituras de poder que los moriscos otorgaron a sus representantes para concertarse con el señor.

En este punto, es preciso insistir en que no es posible conocer con exactitud cuáles pudieron ser las razones que movieron al marqués a pactar con sus vasallos moriscos a cambio de que éstos renunciaran a mantener el pleito. Es de suponer que estaba a punto de pronunciarse en Granada una sentencia contraria a los intereses del marqués, y que éste, conocedor de ello, decidió tomar la iniciativa urdiendo una compleja trama mediante la cual obtuviese los mayores beneficios, esto es, la invalidación del pleito. Es cierto que nos desenvolvemos en el terreno de la conjetura, bien que nada aventurada. Que la sentencia estaba apunto de producirse lo apunta la misma documentación. La documentación señorial parece abundar en la sospecha: una vez firmado el acuerdo, los intentos de revocarlo por parte de algunos vecinos que no habían participado en el asunto serían sistemáticamente rechazados por el marqués. Incluso éste envió a la corte un solicitador para pedir confirmación de la escritura de "transación" realizada con los vecinos de Vélez Blanco ${ }^{15}$. Las instrucciones precisas que se remitieron al solicitador pretendían hacer frente a una escritura de contradicción del pacto firmada por los vecinos que no habían participado del acuerdo. El marqués intentará, por todos los medios posibles, que el "acuerdo y pacto parcial" tuviera ca-

14. De cuyo peligro ha advertido en reiterados foros el profesor Bernard Vincent.

15. ADMS, Leg. 459. El documento se encabezaba asî: "Lo que se a de advertir al solicitador que el muy excelente señor marqués de Vélez tiene en la corte de su magestad açerca de la confirmaçión que pretende pedir a su magestad en el escriptura de transación que se a hecho con el conçejo e vezinos desta villa de Vélez el Blanco sobre los pleytos que se tratavan en la Real Audiencia de Granada sobre estancos y otras cosas es lo siguiente". 
rácter de "total"; exactamente lo contrario de lo que había venido actuando durante muchos años, en que las sentencias "parciales" de la Chancillería habian favorecido en el fondo sus intereses.

El desmesurado afán del marqués de los Vélez por llegar a un acuerdo con los vecinos de Vélez Blanco queda reflejado no sólo en la búsqueda de una alianza con los moriscos sino también en el proceso mismo de negociación. Los representantes de una y otra parte aparecen y desaparecen de las negociaciones sin aparente causa que justifique tales cambios. Solamente permanece la sombra alargada del marqués, sostenedor inefable de un pacto que, a la postre, no será sino un enorme engaño para los más desfavorecidos, para la minoría marginada de aquellas tierras. Los reticentes a la firma del acuerdo o los que lo denunciaron como una gran patraña fueron desapareciendo de las sucesivas escrituras de poderes.

Pero veamos quiénes fueron los representantes de ambas partes. Del lado de los vecinos de Vélez Blanco, las negociaciones, que se inician en enero de 1567, están encabezadas por tres moriscos, García Ramí, Hernando Morcel y Hernando Rapaupe, y un cristiano viejo, Francisco Barriga, tras haber recibido poder de los capitulares del concejo. En principio, de los representantes moriscos el que podríamos calificar de notable es García Ramí, quien figura en una escritura de compra como "procurador"16; él y Hernando Morcel son considerados como "moriscos ricos" 17 . De Hernando Rapaupe no encontramos registros de transacciones económicas significativas en los años precedentes a la firma del pacto, pero se sabe que en mayo de 1568 entrega en dote a su hija Catalina más de 66.000 maravedís para su casamiento con Francisco Dinde ${ }^{18}$. En la negociación, ni los aludidos moriscos, ni el cristiano viejo Francisco Barriga debieron aceptar las condiciones iniciales presentadas por el marqués, pues el 16 de marzo del mismo año de 1567 fueron apartados de la negociación.

En esa fecha, los vecinos revocan el poder anterior y designan como representantes a Hernando Rapaupe, Rodrigo Almorid, Rodrigo Cehel y

16. AHPA, Protocolos, 2952. Escritura otorgada el 31 de diciembre de 1564 ante Bartolomé Sánchez. García Ramí era el miembro más relevante de una familia de cuatro hermanos, Ramón, Rodrigo y García. Cf. J.A. TAPIA GARRIDo, Vélez Blanco, la villa señorial..., p. 139.

17. J.A. TAPIA Garrido, Historia General de Almeria..., IX, p. 143. Hernando Morcel fue llevado a tierras de Cuenca tras la expulsión y portaba bienes muebles por la nada despreciable cantidad de 250.000 maravedís. Cf. J.A. TAPIA GARRIDO, «Expulsión de los moriscos de los Vélez», p. 11. El mismo día que se producía la sublevación de sus hermanos de fe, el 25 de diciembre de 1568, Morcel otorgó una escritura en mancomunidad con Juan Chelen, Luis Alcadí, Luis Almadaque y García Morcel por la cual se obligaban a pagar a un acaudalado cristiano -García de Falces, hermano del beneficiado Martín de Falces- la suma de 26 ducados por una deuda que otro morisco, Alvaro Alcadí, había contraído con Falces (AHPA, Protocolos, 2955, fol. $35 \mathrm{v}$ ).

18. AHPA, Protocolos, 2955,28 de mayo de 1568. 
Martín Chelen. Tan sólo permanece de los comisionados iniciales Rapaupe. Los nuevos representantes forman parte del grupo más poderoso económicamente de la comunidad morisca, de la "pequeña oligarquia" morisca. Rodrigo Cehel y Martín Chelen se hallan en las escrituras notariales previas a 1567 como activos comerciantes de animales de labranza y tiro, un bien que alcanza los valores más altos de cuantas transacciones comerciales se realizan, a menudo por encima de la cotización de casas y tierras ${ }^{19}$. Martín Chelen era además mayordomo del concejo de Vélez Blanco, y por tanto será el nexo de unión entre el concejo y los diputados moriscos designados en esta segunda legación. De Rodrigo Cehel, sabemos además que entre sus ocupaciones se encuentra la del cobro del reparto de la farda a sus correligionarios ${ }^{20}$; cuando fue expulsado del Reino y llevado hasta tierras de Cuenca portaba la suma de 220.000 maravedís en bienes muebles ${ }^{21}$.

La condición económica privilegiada de estos comisionados hace que su relación con sus hemanos de etnia sea compleja: de una parte, de superioridad social, por el indiscutible peso de sus caudales; de otra, de dependencia, pues actúan como fiadores y prestamistas cuando no mantienen deudas directas con ellos como consecuencia de las ventas, con pagos a plazos, de los más diversos animales de labranza. Es decir, forman un grupo de moriscos que tienen poderosas razones como para "convencer" a los miembros de su comunidad de la conveniencia del pacto. Es probable, incluso, que esta minoría privilegiada tuviese relaciones económicas concretas con la casa señorial; pero más importante aún es la evidencia de que de todas las demandas interpuestas por los vecinos contra el marqués esta pequeña oligarquía es la menos agraviada, pues su negocio no dependía exclusivamente ni del trabajo de la tierra ni de la ganadería, que en última instancia son las actividades que suscitan las quejas de los vecinos.

Mas, ¿en nombre de quiénes actúan los diputados moriscos? La pretensión señorial es que no sea sólo en nombre de quienes les han otorgado explícitamente el poder para concertarse. Este es el gran problema que subyace una y otra vez en el desarrollo del conflicto.

Veamos. El día 16 de marzo de 1567 se reúne un extraño concejo en la villa de Vélez Blanco, en la puerta de la iglesia, para otorgar la escritura de

19. AHPA, Protocolos, 2951, 2952 y 2953.

20. AHPA, Protocolos, 2952, 25 de febrero de 1563, fol. 22 r. Junto con García Molón y Hernando de Ubeite, actúa como repartidor de las fardas en 1563, año en el que acude ante el escribano para otorgar un poder a un cristiano viejo, Miguel de Tortosa, a fin de que compareciera ante el tribunal de la Inquisición de Granada y cobrara de los bienes secuestrados por el Santo Oficio a varios moriscos de Vélez Blanco, presos en la cárcel inquisitorial, los maravedís que le pertenecían del repartimiento de la farda de aquel año.

21. J.A. TAPIA GARRIDO, «Expulsión de los moriscos...», p. 11. 
poder. El concejo está formado por un alcalde ordinario morisco, Luis Dinde o Dindi, un regidor morisco, Rodrigo Dinde, y un cristiano viejo, Juan de Jaén ${ }^{22}$. A ellos se les suma el citado morisco, Martín Chelen, mayordomo del dicho concejo. Cuando comparecen ante el escribano alegan que "al presente no son más por aver falleçido y ausentado los demás oficiales del dicho concejo". Es difícil explicar estas ausencias, aunque cabe pensar que fuera por discrepancias respecto de los objetivos de la reunión. Todos ellos habían sido nombrados, alcalde y regidores, por don Luis Fajardo, quien tenía, o se atribuía, esa facultad, según la práctica de su padre, el primer marqués ${ }^{23}$. Sabemos con certeza que en los años previos a los sucesos que relatamos había dos alcaldes, uno morisco y otro cristiano, y las regidurías se distribuían en igual proporción. Extraña, pues, la ausencia de cristianos viejos entre los capitulares del concejo.

Los testigos de aquella escritura de 16 de marzo de 1567 no parecen estar escogidos por casualidad. Amén de un vecino de Almería, Antonio de Quesada, "yntérprete para los que no sabían lengua castellana", figura una nutrida representación del estamento eclesiástico - ¿fueron los moriscos quienes buscaron como testigos a los clérigos?-; tan sólo aparece un cristiano viejo que suele figurar en numerosas escrituras notariales, pues actúa como escribiente de Bartolomé Sánchez, escribano ante quien se otorgó la escritura. Los restantes son Juan Chacón, visitador general del obispado de Almería, el vicario de la iglesia de Vélez Blanco Juan Bautista de Prado, el clérigo y sacristán Gómez Piñero y Pedro de Vargas, también cristiano viejo pero vinculado a la iglesia como notario de la misma. En su calidad de vicario, Juan Bautista de Prado era el encargado de recaudar todas las rentas pertenecientes a la iglesia de Vélez Blanco.

Del lado del marqués, los encargados de la negociación son personajes harto relevantes, y sobre todo, de su total confianza, de su clientela política, y plenamente instruidos acerca de lo que debían negociar para favorecer los intereses de su señor: un regidor morisco de Baza, Bernardino Muñoz, un importante morisco, que es además alcalde ordinario de Vélez Rubio, Juan de Alhariz Aragón ${ }^{24}$, y un individuo, Alonso Rodríguez, que figura en las escrituras como vecino de Vélez Blanco y de Mula, esta última villa también del señorío de los Vélez. Por tanto, dos cristianos viejos y un morisco que tienen en común, amén de la plena confianza del señor, el hecho de no pertene-

22. Su actividad principal parece ser el comercio de paños en Vélez Blanco (AHPA, Protocolos, 2951, 2952, 2953 y 2954).

23. A. FRANCO Silva, El marquesado de los Vélez..., p. 97.

24. Juan Alhariz castellanizaría su apellido como Juan de Ariza. Su cargo de alcalde ordinario y su conocimiento del reparto de las aguas - pues tenía en su poder un "libro escrito en arábigo", que se llamaba el Libro de Condac (F. PALANQUes y AYÉn, Historia de la villa de VélezRubio, p. 93)- no impedirían su expulsión tras la guerra. 
cer plenamente a la población con la que el marqués pretendía sellar el acuerdo.

De los tres representantes del marqués, el personaje más interesante es Alonso Rodríguez. El rastreo sobre su actividad en los protocolos notariales nos permite afirmar que, al margen de la confianza del marqués, es de los más destacados miembros de la oligarquía local velezana merced a su fuerte poder económico; la amplitud y diversidad de sus actividades impiden definirlo de forma precisa: se trata de hombre adinerado que aplica constantemente sus depredaciones sobre pobres campesinos, tanto moriscos como cristianos viejos. Lo hallamos comprando tierras o adquiriendo derechos de agua, actuando como prestamista, hipotecando tierras y casas, como fiador y arrendador de tierras. Entre sus múltiples ocupaciones se encuentra la de "mayordomo mayor de las obras de la iglesia de Santiago", que se estaba construyendo en Vélez Blanco, pues firmó varias escrituras en febrero de 1566 para la entrega de las jácenas de madera que debían cubrir la iglesia ${ }^{25}$. Pero tal vez su fuente de ingresos mayor proviniera de ser arrendador de las alcabalas de labranza y crianza de los cristianos nuevos de Vélez Blanco ${ }^{26}$, así como de las alcabalas de Mula, población en donde figuraba también como uno de los hombres más ricos ${ }^{27}$. Haciendo hueco entre tan variadas actividades, ahora, por encargo del marqués, se prestaba a actuar como agente de una operación "contra los moriscos". Este Rodríguez adoptará más adelante una actitud que bien podría calificarse de extraña; no tanto si se tiene en cuenta que, siendo como era un cualificado exponente de la oligarquía local viejo-cristiana, el pacto se realizaba a espaldas de este grupo. Constatemos simplemente que no figurará entre los firmantes del acuerdo, pero que no desaparecerá del escenario de los hechos.

\section{LA TRAMA}

Entre el comienzo de la negociación, el 24 de enero, y el 16 de marzo se ha producido un significativo cambio en los diputados por el lado de los vecinos: en esta última fecha no queda ya ningún representante de los cristianos viejos: el pacto se tendrá que hacer necesariamente con los moriscos, con nuevos hombres que se muestren más proclives a los intereses del marqués. De esta forma, la firma definitiva representaría, y así fue de hecho, una alianza del marqués contra los cristianos viejos, que seguían manteniendo las demandas contra él.

\footnotetext{
25. AHPA, Protocolos, 2952, 17 febrero 1566 y 17 marzo 1566.

26. AHPA, Protocolos, 2951, 2 octubre 1562.

27. J. GonzAlez CASTAÑo, Una villa del reino de Murcia en la Edad Moderna (Mula), Murcia, 1992, p. 188.
} 
Efectivamente, el día 16 de marzo se nombran a los cuatro moriscos que debían negociar con el marqués. Pero era preciso obtener el poder de todos los vecinos, porque el acuerdo debía de hacerse en nombre del concejo de la villa de Vélez Blanco, reunido en "concejo abierto". Según costumbre, primero se emitieron una serie de pregones públicos por toda la villa; luego, juntos en la iglesia los representantes, llamaron a los vecinos al toque de "campana repicada" - de la campana grande de la iglesia-, consiguiendo la congregación de un total de 190 vecinos ${ }^{28}$. No era la primera vez que los líderes moriscos pretendían reunir a sus correligionarios para el mismo fin; la documentación señorial registra cómo en otras dos ocasiones anteriores lo habían intentado: en una de ellas, llegó a otorgarse poder a la primera comisión arriba aludida, la formada por los tres moriscos y por el cristiano viejo Francisco Barriga. En esta ocasión, el otorgamiento del poder a los nuevos representantes se hizo de un modo harto expeditivo: puesto que la cuestión iba a ser un pacto con los moriscos, excluido Barriga, a los antiguos legatarios no se les daba otra opción "que si quisiesen hallarse con los dichos quatro nuevamente diputados para tratar el dicho conçierto y transaçion lo pudiesen hazer".

En los días siguientes al 16 de marzo, los moriscos comisionados, interesados en obtener la mayor representación posible, inician un recorrido "particular" por las calles y casas de la villa, "sin concejo ni pregón ni campana", hasta alcanzar la ratificación de la escritura por parte de 52 vecinos moriscos más. Estas escrituras se otorgan entre el día 17 y el 25 de marzo de 1567. Las dificultades que debieron tener para conseguir más adeptos a la pretendida causa de concordia quedan reflejadas en las escrituras de ratificación otorgadas el día 18 de marzo, cuando por vez primera aparecen mujeres moriscas, todas ellas viudas, accediendo a dar el poder para pactar con el marqués de los Vélez. En los días siguientes, nuevas viudas se añaden al otorgamiento de poder. Es la forma en que se consigue el consentimiento de un total de 245 vecinos para que los nuevos representantes inicien la negociación con el marqués.

28. En la lista figura un morisco de apellido muy conocido: Luis Abduladín. Es el único, de los 190 que otorgan el poder, que tiene su apellido precedido de "don". Se trata de un "hidalgo morisco", perteneciente a la familia de los Abduladines, que habían servido a los Reyes Católicos en la guerra de Granada, y que participaron incluso en la represión de las revueltas mudéjares del año 1500. En los Vélez, de donde eran alcaides los hermanos Alí y Mohamed Abduladín, fueron los encargados de concertar las capitulaciones en 1488 para la entrega a los Reyes Católicos de Vélez Blanco y Vélez Rubio. En pago de sus servicios recibieron numerosas compensaciones económicas y mercedes. $C f$. J. GRIMA CERVANTES, «Las capitulaciones de 1488 y $1501 \ldots »$, pp. 203-223. A pesar de la probada fidelidad de la familia y de la condición nobiliaria de don Luis Abduladín, fue expulsado tras la rebelión de 1568 y conducido hasta Huete. Cf. J.A. TAPIA Garrido, Historia general de Almerta..., XI, p. 127. Antes de ser expulsado se trasladaría a vivir a Baza, pues en diciembre de 1567 volvió a Vélez Blanco para vender las escasas tierras que tenía. AHPA, Protocolos, 2954. 
La documentación judicial -conservada en el Archivo Histórico Municipal de Lorca- registra sencillamente que el pacto se firmó entre el marqués de los Vélez y los moriscos de Vélez Blanco. La documentación señorial, que habla de un total de 250 vecinos, "poco más o menos", favorables al concierto, es más explícita y reconoce que "aún quedaron casi otros tantos cristianos nuevos que no quisieron otorgar más el dicho poder, y cristiano viejo ninguno, diziendo quellos jamás truxeron pleito con el marqués ni lo avían de tener, y que por esto no era menester que otorgase poder. $Y$ debaxo de esta buena yntinçion hízose tan pesado el tratar con ellos que se dexó por no mover umores ${ }^{\prime 2}$.

Los datos coinciden. En efecto, la población total de Vélez Blanco en la fecha de la sublevación se cifra en torno a los 600 vecinos $^{30}$, de los cuales los moriscos supondrían algo más de los dos tercios ${ }^{31}$. Pero lo más trascendental es el problema de la representatividad. El poder se otorga en nombre del concejo, pero sólo poco más de un tercio de sus vecinos ha dado su consentimiento para pactar con el marqués, y ni un cristiano viejo. La causa de la exclusión de este grupo no era, como la documentación señorial afirma, que no mantuviesen pleito alguno con el marqués: problemas como la apropiación del monte y de los baldíos por parte del señor afectaba por igual a moriscos y a cristianos viejos. Las razones de esta actitud eran bien distintas como desvelaremos más abajo, una vez consumado el pacto entre el marqués y los moriscos.

Designados los nuevos representantes moriscos -Rapaupe, Almorid, Cehel y Chelen- éstos se reúnen con el marqués y con dos personas de su misma lengua, los referidos Juan Alhariz, alcalde de Vélez Rubio, y Bernardo Muñoz, regidor de Baza. Las negociaciones entre ambas partes duran hasta el día 7 de junio en que se firma la concordia. Entre el 25 de marzo y el 7 de junio, después de aver "pasado muchas alteraciones y pesadumbres, acabáronse de concertar y concluir los capítulos del concierto" 32 , no sin antes -de modo paralelo a la negociación- haber intentado que nuevos vecinos se sumaran al otorgamiento de poder. Los firmantes pensaban que una vez formalizado el acuerdo los cristianos nuevos que faltaban por suscribir el poder lo harían; luego, la realidad demostró lo contrario.

Mención especial requiere el capítulo de testigos de la escritura de concordia. Además de los representantes designados por el marqués para la

29. ADMS, Leg. 459. Relación de lo que pasa en el negoço y conçierto que con el marqués an tratado los moriscos de Vélez el Blanco.

30. P. AlcAínA FerNÁNDEz, "Vélez Blanco en el siglo XVI», en Vélez Blanco nazarita y castellano, p. 97.

31. ADMS, Leg. 1655.

32. ADMS, Leg. 459. Relacion del concierto... 
firma, y de los escribanos Miguel de Molina y Aparicio López, se encuentra toda la clientela del marqués de los Vélez. En la casa del alcalde mayor de Lorca se dan cita numerosos deudos del marqués: el licenciado y regidor de Lorca Martín Hernández Manchirón, Gaspar Hernández Camacho, secretario del marqués, Bartolomé Sánchez, escribano público de Vélez Blanco, Juan de Lezana, vecino de Almería, Hernando de León, alguacil mayor de Mula, y Pedro de Ledesma, vecino de Granada. Todos ellos figuran en los registros de escrituras de los protocolos notariales de los años previos a 1567. Así, Juan de Lezana aparece en un acta notarial en la que entrega a otro hombre de la clientela del marqués, Jaime de Santonge, una suma de dinero para que la invierta en las ferias de Úbeda y Baeza ${ }^{33}$; en varias actas figura como "criado y solicitador" de la casa señorial del marqués de los Vélez ${ }^{34}$. Hernando de León es probablemente hijo de un vecino de Vélez Blanco del mismo nombre. Pedro de Ledesma aparece en diciembre de 1567 como testigo de un acta por la cual Alonso Rodríguez -representante del marqués para la firma de la concordia- hipoteca una tierra con su agua a una familia morisca ${ }^{35}$. Por el otro bando, el de los moriscos, ninguno sabe firmar, ni siquiera el alcalde de Vélez Rubio, que representa al marqués de los Vélez. En su nombre firmará toda la clientela del marqués.

A partir de la firma de la concordia, los moriscos se dividen en dos bandos claramente enfrentados, partidarios y opositores del acuerdo con el marqués. Los partidarios están encabezados por los propios diputados para la negociación. La posición contraria la lidera un cristiano viejo que había sido comisionado inicialmente para el mismo fin: el ya citado Francisco Barriga. $\mathrm{Ni}$ éste ni los tres moriscos que inicialmente habían sido designados para negociar firman el poder para concertarse con el marqués. Tienen sobradas razones para ello, porque desde el primer momento conocen los objetivos de don Luis Fajardo, y tienen plena conciencia de que se trata de una estrategia para perpetuar cuantas usurpaciones de derechos había perpetrado. El contenido mismo del pacto dará la razón a Francisco Barriga y a los que abandonaron la comisión primera. Pero eso se narra más adelante.

El tal Barriga se enfrentó directamente a los nuevos diputados moriscos: "dava bozes dende la yglesia donde estava retraydo por otras cosas, pero no que dixese querer hallarse en ello syno que los engañavan y los di-

33. AHPA, Protocolos, 2953, fol. 100 r. En total le había entregado a Santonge la suma de 280 ducados (escritura otorgada el 5 de agosto de 1567). Esta suma la incrementó con nuevas entregas el 1 de abril de 1568, por importe de 90 ducados, para emplearlos en "mercadurias y tratar con ellos" (AHPA, Protocolos, 2955, fol. 81 r), y 50 ducados, el 9 de agosto del mismo año (ibídem, fol. $115 \mathrm{r}$ ). Es posible que estas entregas de dinero las hiciese en nombre del marqués de los Vélez en su calidad de solicitador de negocios de la casa señorial.

34. AHPA, Protocolos, 2955, fol. $87 \mathrm{r}$.

35. AHPA, Protocolos, 2955, fol. $52 \mathrm{r}$. 
chos quatro últimos diputados vendían al pueblo, y otras vellaquerías desta manera para amotinar a los otorgantes que rebocasen a los demás que no otorgasen" ${ }^{\prime 36}$. Los compañeros moriscos de Barriga en la primera comisión negociadora no quisieron sumarse al pacto con el marqués, salvo Rapaupe, que se integró en la nueva comisión. Según la documentación señorial, Morcel no contradecía el pacto, pero tampoco quería otorgar el poder para participar en el mismo, señalando que lo "que los otros hiziesen tendría por bien hecho". Por su parte, García Ramí "callaba en lo público", pero en privado estaba claro que mostraba un rechazo frontal del acuerdo.

Que la oposición al pacto la abanderara un cristiano viejo no preocupaba en exceso al marqués. Más le inquietaba la posibilidad de que un morisco, García Ramí, encabezara un movimiento contrario a sus intereses. La solución fue contundente: eliminar a García Ramí, apartarlo de Vélez Blanco. Para ello ideó el marqués una estrategia que le daría los resultados apetecidos de inmediato: se trataba de mantener preso a Ramí fuera de Vélez Blanco, mientras duraba la negociación, con el fin de que no pudiese aglutinar a los moriscos opuestos al pacto.

La trama, perfecta, adquiere tintes novelescos -a la vez que introduce una nueva dosis de "veneno documental"-. El tal Ramí fue a comprar trigo a Las Cuevas para su casa, "y Melchor de Torres, que por la biuda de Benito de Aconte entiende aquí en su execución, viendo que la justicia desta villa andava en ello floxa, fue a Las Cuevas, y a su pedimento la justicia della prendió al dicho Ramí como a prinçipal obligado contra quien se hazía la execución, y asy lo tiene preso en aquella cárcel hasta aora, y acá executa en los bienes que tiene en esta villa" ${ }^{37}$. El apresamiento de Ramí sentó mal a dos de los nuevos delegados moriscos, pero no importó demasiado al marqués ya que se había cumplido su principal objetivo. Se trataba de alejarlo del lugar de negociación, pues de ello se sigue "harto provecho de no poder andar aquel malinando en esta villa y otras partes" 38 .

García Ramí permaneció en la cárcel de Las Cuevas mientras duró la negociación entre el marqués de los Vélez y los moriscos. Todavía el día 9 de agosto estaba allí preso, pues ese día comparecen dos moriscos ante el escribano de Vélez Blanco, Bartolomé Sánchez, y se obligan a pagar la deuda que tenía contraída García Ramí, a causa de la cual había sido ejecutado en sus bienes y hecho preso ${ }^{39}$. En apariencia se trata de una escritura intrascendente que podría haber estado alentada por la solidaridad de los moriscos que pretendían liberar a Ramí. La cuestión es que los moriscos que se presentan

\footnotetext{
36. Ibidem.

37. Ibidem.

38. Ibidem.

39. AHPA, Protocolos, 2953 , fol. $72 \mathrm{r}$.
} 
ante el escribano son personajes conocidos de nuestro relato: Rodrigo Cehel y Rodrigo Almorid, dos de los diputados moriscos que el 7 de junio habían firmado en Lorca la concordia con el marqués. Ambos se obligan, en el plazo de tres días, a pagar 600 ducados que se debían a Benito de Aconte. ¿Cuál era el origen de la deuda de Ramí con Aconte? Nada más y nada menos que los "salarios por la solicitud de los pleitos que el concejo e vecinos desta villa an contraydo con el muy eçelente señor marqués de los Vélez" ${ }^{\prime \prime}$. Entre los testigos de esta escritura se encuentra otro personaje que el "azar" sitúa en el negocio del acuerdo: Juan Alhariz Aragón, alcalde de Vélez Rubio y representante del marqués en las negociaciones.

No estamos ante una ficción ni ante las intrigas de un relato novelado. García Ramí, que había sido comisionado "junto con otros consortes" para defender los derechos moriscos frente al marqués, sufre en su propia piel la ejecución de sus bienes por las deudas que mantienen "todos los vecinos moriscos" con el solicitador de pleitos. En pleno proceso de negociación, el marqués da una vuelta a la tuerca para forzar a que los moriscos pacten. Y lo hace sobre su mismo pleito, apresando al principal opositor por las deudas que los moriscos mantienen con quien les defiende en la Chancillería de Granada. La presencia de otro delegado del marqués y partícipe del acuerdo, Juan Alhariz, junto con los dos moriscos que actúan como fiadores y que vienen de firmar el acuerdo en contra de la voluntad de la mitad de los moriscos, y del propio Ramí, induce a pensar que el pago de la deuda pudo salir de la propia hacienda señorial. Si además del pacto escrito, hubo -como muy verosímilmente cabe suponer- un pacto secreto entre los negociadores, tal vez éste incluyó el pago por parte del marqués de lo que habían supuesto las "costas" del gravoso pleito de tantos años. El marqués de los Vélez probablemente prefirió pagar esta suma y obtener un acuerdo muy favorable para sus intereses, antes de que se pudiera consumar una sentencia contraria a tan vitales intereses. Como dato añadido, que abunda en la perfecta estrategia dibujada, días antes de hacerse esta escritura de obligación, el 4 de agosto de 1567, Melchor de Torres, que en nombre de la viuda de Juan de Aconte había ordenando el apresamiento de García Ramí, comparece ante el escribano para permitir el traslado de Ramí de cárcel, "porque muchas personas le an rogado dé horden para traherlo a esta villa o a la villa de Vélez el Ruvio para que pueda pagar" la deuda que él y "sus consortes" mantienen con Juan de Aconte ${ }^{41}$. Se acerca a Ramí al escenario de los hechos para que sus

40. Ihidem.

41. AHPA, Protocolos, 2953, fol. 73 r. Como testigos de esta escritura figuran nada menos que los dos alcaldes ordinarios de sendas villas, Luis Dinde, de Vélez Blanco, y Juan de Alhariz, de Vélez Rubio; dos personajes que se mueven claramente en los círculos clientelares del marqués de los Vélez. 
vecinos vean quién y por qué lo han liberado. Se trata de sumar adeptos a un pacto que cuenta con más enemigos que seguidores.

Pero los avatares sufridos por García Ramí no finalizan con su acercamiento a las cárceles velezanas y el pago de la deuda por los pleitos que había traído con el marqués. La estrategia, con toda probabilidad diseñada por el marqués de los Vélez o sus servidores -cabe subrayarlo una vez más-, da los resultados apetecidos muy pronto, tal como lo acredita una escritura otorgada en Lorca el día 17 de agosto de 156742: Ramí ha salido de la cárcel; el opositor radical que habíamos conocido antes de su ingreso en prisión llega a Lorca para ratificar la escritura de transacción otorgada el mes anterior por los moriscos de Vélez Blanco; la fuerza de la prisión y del pago de los 600 ducados han sido los argumentos de su cambio. García Ramí, inquietante cabecilla de la causa morisca, finalmente ha claudicado, ha quedado prendido en la red señorial.

La ratificación de la transacción por parte de García Ramí significa todo un acontecimiento en el proceso. En Lorca le esperan los mismos protagonistas de la firma de la concordia, el escribano Miguel de Molina, el receptor de la Chancillería de Granada, Aparicio López, y el licenciado Duarte, alcalde mayor de Lorca. En el acta notarial se trata de justificar la ausencia de Ramí durante la firma de la concordia en el mes de junio. Se escribe que no se pudo hallar por estar "justamente impedido", pero se tacha esta expresión y se anota por estar "fuera de la villa".

Pero más ilustrativo aún es el procedimiento por el cual se hace la ratificación de García Ramí. No firma en su nombre sólo, sino también en nombre del concejo de la villa de Vélez Blanco, "usando de la facultad que a él se le dio por el dicho poder que el dicho conçejo e vecinos otorgaron" a los moriscos firmantes; y lo hace "como si el dicho Garçía Ramí se hallara presente al otorgamiento". Así pues, la aceptación del acuerdo es plena. Hace valer incluso el primer poder que a él le otorgaron los moriscos de Vélez Blanco y que fue anulado ante su negativa a negociar el acuerdo que pretendía el marqués. Pero los servidores del marqués no se fían plenamente de Ramí y le obligan a que en la misma escritura de ratificación de la concordia haga un juramento ante el alcalde mayor de Lorca en los siguientes términos: "Y para mayor balidación e firmeça, el dicho Garçía Ramí dixo que juraba por Dios todopoderoso e por Santa María e por las palabras de los Santos Evangelios e por la señal de la Cruz, e que puso su mano derecha en la cruz de la vara de el muy magnífico señor licenciado Duarte de Aquino, alcalde mayor en la dicha çibdad de Lorca"43. De este modo tan significativo claudicaba el principal opositor al pacto con el marqués de los Vélez.

42. AHML, Protocolos, 69, fol. 230.

43. Ibidem. 
Con el otro gran opositor, el cristiano viejo Francisco Barriga, en pleno proceso de negociación, acaece otro hecho que, aunque no tenemos certeza absoluta, parece ir encaminado en el mismo sentido, apartarlo del lugar de las negociaciones. El día 13 de mayo de 1567 comparece ante el alcalde ordinario Luis Dinde un preso de la cárcel llamado Diego Ordóñez, y lo hace para denunciar un suceso acaecido en $1566^{44}$. Ordóñez declara cómo aconsejado por otros presos envió un escrito al marqués de los Vélez, por orden de Francisco Barriga, en el que se querellaba criminalmente contra Diego de Villarroel, alguacil mayor de Vélez Blanco, diciendo que el dicho Villarroel había "dormido y echádose carnalmente con Juana Vázquez, mujer del dicho Ordóñez, por fuerça y contra su voluntad"; al tiempo que también se querellaba contra Mari López, mujer de Vicente Español, que era carcelero de la citada prisión, alegando que la tal Mari López había engañado a Juana Vázquez y concertado el día y lugar para forzarla. Ordóñez confiesa ahora que todo aquello es falso y que mal aconsejado había sido instigado para enfrentarlo con el alguacil y junto con los demás presos romper la cárcel y emprender la fuga. Entre los testigos de la escritura figura Alonso Rodríguez, representante del marqués de los Vélez en la negociación de los moriscos. Estos hechos pueden ser una simple casualidad pero lo cierto es que se trata de acusar de toda la trama a Francisco Barriga. La nueva acusación no debió surtir los efectos oportunos, pues Barriga estaba libre cuando se concluyó el acuerdo.

Neutralizados, y aun ganados, de una u otra forma, Ramí, Morcel y Rapaupe, la única resistencia al pacto con los moriscos quedaba en este cristiano viejo, Francisco Barriga. Un año después, en mayo de 1568, lo encontraremos en la cárcel de Vélez Blanco. Lo más interesante es conocer quién es la autoridad encargada de su prisión. El alcalde ordinario de Vélez Blanco ya no es Luis Dinde, sino un viejo conocido de esta historia, el morisco Martín Chelen ${ }^{45}$, uno de los cuatro firmantes de la concordia de junio de 1567. Es una evidencia de que don Luis Fajardo debió recompensar con generosidad a los moriscos colaboradores.

Interesa resaltar un episodio que ilustra el control que el señor, el marqués, detentaba sobre el funcionamiento de la justicia, la justicia señorial, y sobre los cargos interpuestos, como los de alcalde ordinario y alguacil, meridianamente manifestado en la escritura que sirve esta información. Martín Chelen y el alguacil Rodrigo de Mula habían recibido una notificación del provisor del obispado de Almería, a petición de Francisco Barriga, preso en la carcel pública, para que comparecieran ante el provisor por haber sido apresado y "sacado de lugar sagrado" el dicho Barriga. Su comparecencia

44. AHPA, Protocolos, 2953, fol. $28 \mathrm{r}$.

45. AHPA, Protocolos, 2955, fol. $106 \mathrm{r}$. 
ante el notario era para dar un poder a Francisco Caicedo, escribano del partido de Oria, para que en su nombre alegase ante el provisor que éste no tenía jurisdicción alguna contra ellos y que no eran competentes en este asunto. Martín Chelen y Rodrigo de Mula dicen comparecer en su nombre, pero en la tachadura -bien significativa- puede leerse que tal comparecencia la hacían "en nombre de su excelencia" 46 .

\section{EL PACTO}

Volvamos al año de 1567. Corre el día 7 de junio, fecha en que el marqués de los Vélez ha dado poder a Bernardino Muñoz, Juan Alhariz y Alonso Rodríguez para firmar el concierto; junto con los representantes moriscos, Cehel, Chelen, Almorid y Rapaupe, parten hacia Lorca, de noche, sin duda para "no ser vistos" por la población de Vélez Blanco. La "huida", además, se hace hacia un lugar determinado por el marqués por la seguridad y confianza que le ofrece, nada menos que la casa del alcalde mayor de Lorca. Allí, en su presencia, y ante el escribano Miguel de Molina y Aparicio López, receptor del número de la Chancillería de Granada, se firmará el pacto. Según consta en la documentación notarial, se utiliza como modelo una escritura, enviada desde Granada, conteniendo el acuerdo signado entre el conde de Ureña y su villa de Morón. Será el domingo día 8 de junio.

Mas, pese a las cautelas, los firmantes y testigos iban a recibir una gran sorpresa: la súbita visita de Francisco Barriga, quien enterado de que iba a firmarse el pacto, se presenta en la casa del alcalde mayor de Lorca. Desde la iglesia de Vélez Blanco había seguido los pasos de los diputados moriscos y representantes del marqués. "Con grandes bozes y desvergüença acostumbrada, dixo que yba a hallarse en ello por el dicho poder queste conçejo e vecinos le otorgaron" 47 . Los cuatro procuradores moriscos le respondieron que se alegraban de que estuviera con ellos; los representantes del marqués callaron. Los documentos señoriales describen con minuciosidad lo que sucedió a continuación, ni que decir tiene que con la parcialidad presumible, traducida en palabras insultantes para Barriga. Éste "començó a dezir que aquellos procuradores venían allí por fuerça, engañados; a lo qual los dichos quatro le respondieron que mentía, que no venían sino por su voluntad, porque cumplía a la villa la dicha escriptura de conçierto e transaçión que estavan otorgando; e como el vellaco vio esto, salióse y dexólos a todos antes de acabarse de leher" ${ }^{\prime 48}$.

\footnotetext{
46. Ibidem.

47. ADMS, Leg. 459.

48. lbidem.
} 
Si el contenido mismo del acuerdo iba a ser un gran engaño, la mayor falsedad estaba aún por llegar. Se planteaba una vez más el problema de la representación que ostentaban los moriscos comisionados para la firma. En la escritura de la concordia los delegados del marqués pretendieron poner que los delegados moriscos se obligaban por ellos, por el concejo y por los demás vecinos que eran o fueren en adelante de Vélez Blanco. A esto se opusieron los cuatro moriscos que alegaron que no firmarían en nombre de quienes no les habían otorgado poder. Era escollo tan difícil que en última instancia podía frustrar el acuerdo. Las presiones de la parte señorial son fuertes: "que bien sabían que el conçierto devían de hazer en otrogar en nombre de toda la villa e que así se les avía dicho aquí muchas vezes e lo avían llevado entendido" 49 . Los procuradores del marqués simplificaban las razones de los diputados moriscos arguyendo otras de particular egoísmo: "áseles metido miedo en la cabeça de que si se obligan por los que no an dado poder pagarán ellos todas las penas si aquellos no guardan el conçierto".

La realidad era, empero, un grave problema de representación: la delegación morisca se mantenía cuidadosa de que la escritura de concordia se firmase tan sólo en nombre de quienes verdaderamente habían otorgado el poder, no por los demás. Fue la habilidad de los escribanos elegidos por el marqués de los Vélez y las justicias de Lorca la que posibilitó, al menos ante los ojos del señor, la interpretación jurídica amplia que perseguía. En el mismo mes de junio, un servidor del marqués que participó en aquel acuerdo anotaba como final de su descripción de los acontecimientos del pacto que "está de tal manera lo que se hizo en Lorca que, si se tiene por bueno, de aquella manera queda hecho e otorgado, y si no se tiene por tal, queda por no hecho; aunque los dichos quatro moriscos no lo entienden ni así, sino que ya está hecho en quanto toca a ellos, e al concejo e a los que dieron poder; pero aunque crehen esto ay la libertad dicha" ${ }^{\prime 50}$.

Al margen del problema de la representatividad, el 8 de junio de 1567, después de siete meses de negociaciones, se llega finalmente a la redacción y firma del acuerdo. Los diputados moriscos, atrapados en las redes del marqués y sus justicias, afirman que proceden al pacto porque piensan que el "fin de los pleitos es dudoso, y la justiçia clara que el dicho señor marqués tiene en ellos, e las grandes costas que ellos se an hecho y hazen". Por tanto, se presenta como la mejor salida posible ante una nada improbable sentencia desfavorable de la Chancillería de Granada. El marqués de los Vélez, por su parte, acelera el proceso, no tan seguro de su éxito ante la justicia de Granada.

\footnotetext{
49. Ibidem.
}

50. Ibidem. 
Al margen de como una y otra parte vieran el acuerdo, la realidad es que la "concordia e transaçión" fue un gran engaño, perpetrado alevosamente por el poderoso, que le iba a permitir perpetuar las usurpaciones y abusos sobre la comunidad morisca ${ }^{51}$. Sólo se incluyeron algunos puntos de reclamación de los moriscos; de los fundamentales no se hizo mención, es decir de aquellos que eran más específicamente sustanciales para las arcas señoriales. La renuncia a los pleitos fue la consumación de la entrega.

Las cuestiones en las que el marqués cedía eran acordadas con minuciosidad para "rellenar" ampliamente la escritura. Además, tras cada tema que se incluía en la concordia, los moriscos acataban una fórmula, según la cual renunciaban a los demás pleitos que tenían pendientes con el marqués: "açevtaban lo que su señoría por este capítulo les da, conçede y acreçienta, y por razón dello y de lo demás que se contiene en esta escritura se disienten y apartan de los dichos pleytos y hazen esta dicha transaçión" 52 .

He aquí el detalle de la concordia en sus aspectos más significativos. Don Luis Fajardo y sus sucesores, cada vez que tomasen las acémilas de los vecinos de Vélez Blanco, pagarían unas cuantías por cada animal y por cada hombre que las llevase ${ }^{53}$, y lo mismo harían en el caso de las bestias asnales y caballares ${ }^{54}$. Se comprometían también a pagar salarios por los servicios de los vasallos, bien por trabajar en las obras de sus edificios -aunque esto ya se practicaba con anterioridad, y lo que se pactaba ahora era una subida en los sueldos $^{55}$-, bien por servir como mensajeros ${ }^{56}$. En cuanto a los abusos que

51. Para desdicha de don Luis Fajardo, la guerra de 1568-1570 -en la que él mismo sería gran adalid de las tropas cristianas-y la expulsión de los moriscos acabarían truncando sus deseos. La nueva repoblación con cristianos viejos se convertiría en un duro revés para sus intereses. Véase al respecto: F. ANDÚJAR CASTILLO, «Señores y Estado en la repoblación de Felipe II...».

52. AHML, Protocolos, 69, fol. $296 \mathrm{v}$.

53. Se estipulaba el pago de una cuantía de 3 reales por día y animal, más una ración de comida para la persona que la llevase, compuesta por dos libras de pan, una libra de carne de macho y medio azumbre de vino, además de celemín y medio de cebada para la acémila. Estas cantidades eran inferiores -56 maravedís - en caso de que las necesidades de la casa señorial se limitasen al uso de la acémila (AHML, Protocolos, 69, fol. 296 r).

54. Se establecía el pago de 83 maravedís por animal al día, 45 por el trabajo del hombre que la llevase y si fuese necesario otro hombre 37 maravedís más (AHML, Protocolos, 69, fol. 297 r). En el caso de las bestias caballares que pudieran cargar 12 arrobas se pagaría lo mismo que lo acordado para las acémilas (AHML, Protocolos, 69, fol. $297 \mathrm{v}$ ).

55. El jornal diario que abonaba el marqués a los obreros era de un real por día "y algunas vezes menos". A partir del acuerdo, los salarios serían de real y medio, desde el 1 de septiembre al 1 de abril, y una cuantía mayor, 60 maravedís, desde abril a fin de agosto, fechas en las que los campos demandarían mayor mano de obra (AHML, Protocolos, 69, fol. $298 \mathrm{r}$ ).

56. En el caso de los mensajeros, el acuerdo establecía la equiparación de los pagos entre cristianos viejos y cristianos nuevos, aunque el marqués rechazaba la acusación de no haberles pagado salario alguno hasta entonces por ese trabajo. La cifra que les pagaba era de un real por día "y a vezes menos" (AHML, Protocolos, 69, fol. $298 \mathrm{v}$ ). 
cometían los criados del marqués al alojarse en casas de los vecinos y alquilar mientras las suyas, el señor no renunciaba a este derecho de hospedaje, aunque para evitar precisamente tales abusos limitaba el tiempo del alojamiento a dos meses y prohibía que los así aposentados pudiesen llevarse las camas y ropas al finalizar el hospedaje.

Eran asimismo "concesiones" del marqués comprometerse a pagar a los moriscos una cantidad de dinero por llevar el trigo y cebada de los diezmos desde sus eras a la tazmía que el señor tenía en la villa de Vélez Blanco ${ }^{57}$. Nótese que hasta entonces, los moriscos tenían obligación de entregar el diezmo al marqués en su tazmía, corriendo ellos con los gastos de transporte. Por lo que hacía a la venta de carneros, el marqués negaba haber influido para que tuviesen que venderlos a las personas que él ordenaba; no obstante, se explicitaba la libre venta en adelante, con tal de que se pregonase un día la venta, y en caso de que el concejo no contase con abastecedor de la carne y se viese en la necesidad de tomar los carneros el pago se hiciese según la tasación realizada por dos personas. Se liberaba asimismo a los vecinos de la obligación de llevar a cocer el pan al horno del señor. Por último, el marqués se comprometía a pagar a los vecinos cada vez que necesitase tomar alcaceres para sus caballos y acémilas.

Pero el acuerdo contenía una pérfida trampa para los vecinos moriscos. Entre las demandas contenidas en el pleito habían denunciado la duplicidad en el pago de las alcabalas, pues debían de abonarlas a la persona que tenía el encabezamiento y al mismo tiempo al propio marqués. Según se hizo constar en la escritura de concordia, las alcabalas de la labranza y crianza, así como las del viento, de cristianos nuevos, desde 1546 hasta abril de 1567, las habían dejado de pagar los moriscos. Dado que antes se habían encabezado estas alcabalas en una suma de 1.100 ducados anuales, el marqués de los Vélez reclamaba una deuda total de 19.400 ducados, cantidad resultante una vez descontadas las de lo recaudado por sus fieles y cogedores de algunos años que se habían encabezado. Según la letra de la concordia, los vecinos pidieron al marqués que rebajase la deuda, a lo cual éste respondió condonándola.

¿Qué obtenía el marqués de tan graciosa concesión? Nada más y nada menos que la aceptación por los moriscos de dar por "ningunos e de ningún valor y efeto los procesos, autos y probanças y escrituras e autos pronunçiados en el ynterin por su magestad e por los dichos señores de su Real Audiençia de Granada e todo lo demás contenido en la executoria e executorias e qualesquier otras provisiones que por razón de los dichos pleytos en nuestro favor se an dado" 58 . Cabe recordar que en los años 1558, 1559, 1560 y

57. Pagaría 4 maravedís por fanega de trigo y 3 por la de cebada.

58. AHML, Protocolos, 69, fol. 303 r. 
1561, los vecinos moriscos habían obtenido unas "sentencias interinas" francamente favorables. Además, los diputados moriscos reconocen que todo se ha hecho "en notoria y evidente utilidad e provecho e bien público e universal del conçejo e vecinos e moradores de la dicha villa de Vélez el Blanco e república della" ${ }^{\prime 59}$. Costaba tanto entender los términos del acuerdo que en la misma escritura se obligó a hacer constar que los delegados moriscos confesaban haber otorgado la escritura por su libre y "expontánea" voluntad, sin que se les hubiera hecho fuerza, ni apremio ni "ynduzimiento" alguno. Por si no fuere suficientemente categórica la formulación, los moriscos diputados renunciaban, tanto por ellos como por sus representados, a que se pueda alegar "que fuimos engañados en más de la mitad del justo preçio ni en otra manera alguna". Es más, no se podría tampoco contradecir lo pactado so pena de pagar la elevada suma de 10.000 ducados, a repartir la mitad para la cámara real y la otra mitad para el marqués. Pero las seguridades para que no se modificara en adelante la escritura van más allá aún: en caso de contradecirla, perderían los 19.400 ducados que se les habían perdonado por la firma de la misma, lo que venía a totalizar una "seguridad" de casi 30.000 ducados, un techo demasiado alto que la blindaba de cualquier veleidad.

Por si no fuera sufiente cautela, los delegados moriscos -en esto, representando a todos los vecinos, sin exclusiones- revocaban todos los poderes, tanto generales como particulares, que habían otorgado a los procuradores para seguir sus causas ante la Chancillería de Granada, entre ellos a un vecino de Vélez Blanco, Pedro Palomar, y a Juan de Santacruz, y por supuesto los que antes se otorgaron en relación con la futura concordia a Francisco Barriga, García Ramí y Hernando Morcel, más o menos pertinaces opositores. En este caso, la representatividad se altera de forma flagrante para acordar por encima incluso de quienes a su vez tienen poderes de los vecinos moriscos para pleitear con el marqués. Se extendió nuevo poder a Jusepe de Quirós, procurador en la Chancillería de Granada, y a Diego de Caicedo, vecino de Vélez Blanco, para que notificasen esta revocación a todos los letrados, procuradores y solicitadores que entendían en los dichos pleitos. Un categórico juramento por Dios, la Virgen y los Evangelios, poniendo la señal de la cruz en la vara del alcalde mayor de Lorca, sellaba simbólicamente la inamovilidad del acuerdo.

Mas el principal beneficio que obtuvo el marqués de los Vélez de la concordia fue precisamente todo el conjunto de asuntos que no fueron ni siquiera objeto de negociación. El objetivo perseguido con mayor afán y que, a la postre, constituiría la esencia del gran fraude en que se convirtió la concordia, fue el mantenimiento de una serie de derechos en poder del marqués que le proporcionaban las mayores rentas y propiedades. Era un corola-

59. AHML, Protocolos, 69, fol. $304 \mathrm{r}$. 
rio de la renuncia a los pleitos, la aceptación de cuantos "derechos" se había subrogado el marqués. Don Luis Fajardo cedía ante la mayor parte de las demandas, pero las omitidas eran las verdaderamente sustanciales: de hecho, y ciertamente en virtud de la concordia, desde 1567 pasaba a ser propietario de los montes, de los baldíos y de las dehesas para el ganado.

La facultad de roturar nuevas tierras, que graciosamente concedía, no era sino una práctica que lo ejercía "de tiempo inmemorial", a modo de derecho. A partir de la firma de la concordia, la ejerció con toda propiedad. El repaso de los asientos del Libro de mercedes del marqués de los Vélez es bien expresivo entre 1551 y 1568. Las licencias para roturar se interrumpen justo cuando los vecinos obtienen una sentencia favorable permitiendo la libre roturación, en el año 1559. En espera de la resolución judicial definitiva, las mercedes de tierras se suspenden, y no volverán a anotarse hasta 1567, una vez consumada la concordia. Estas tierras se pondrán en explotación a condición del pago de una serie de derechos al señor -no es casual seguramente que entre los nuevos beneficiarios de estas mercedes de tierras aparezca algún sujeto conocido de nuestra historia: Hernando Rapaupe recibirá en abril de 156830 fanegas de sembradura; Rodrigo Cehel, 45, ambos en el término de Vélez Rubio ${ }^{60}$.

Lo mismo sucede con el aprovechamiento del monte y de las dehesas. La corta de madera y leña la regula el marqués mediante unas ordenanzas según las cuales la concesión de licencias es competencia exclusiva suya. Los aprovechamientos del monte son múltiples, pero sobre todo se trata de tierras susceptibles de ser roturadas y puestas en cultivo. El acotamiento de las dehesas no es algo baladí. Cabe avanzar que la ganadería en la zona, aún no estudiada, tiene tal vez más importancia que la agricultura; detrás de la actividad ganadera se encuentran dinámicos comerciantes genoveses que mediante una práctica muy conocida entre su comunidad adelantan cada año el dinero a los ganaderos a cuenta de la lana que sus rebaños producirían al año siguiente. El arrendamiento de las dehesas proporciona por tanto importantes ingresos a su propietario, etc.

Como gran conclusión general puede afirmarse sin ambages que, merced a la concordia, el marqués de los Vélez pasará de señor "jurisdiccional" a señor "territorial", al menos de todo el espacio no cultivado. Es igualmente significativo que tal atribución, una flagrante usurpación en definitiva, no se hará sólo en detrimento de los moriscos, sino también de los vecinos cristianos viejos. Por ello, cabe colegir que la estrategia dibujada por el marqués no tendría como objetivo único el pacto con los moriscos, sino la imposición de unas normas de mayor alcance, en tanto afectaba al conjunto de la comunidad de su villa señorial de Vélez Blanco. De ahí el empeño de obtener la re-

60. ADMS, Libro de mercedes... , 6 y 10 de abril de 1568, respectivamente. 
presentación del concejo. El derecho sobre la propiedad de los baldíos, montes y dehesas no era un asunto de cristianos nuevos o viejos sino de toda la población de Vélez Blanco; los moriscos, en última instancia, fueron un mero instrumento, el más maleable dadas sus circunstancias, para que el marqués diese un golpe de mano en sus atribuciones jurisdiccionales.

\section{LA HISTORIA SE INVIERTE: LOS CRISTIANOS VIEJOS SE REBELAN}

El montaje orquestado por don Luis Fajardo para "concertarse" con los moriscos - cuando lo que pretendía en el fondo era incrementar sus derechos a costa de sus vasallos, sin distinción alguna de su condición u origen étnicoreligioso- no termina con la firma de la escritura de concordia del 8 de junio de 1567, pues los cristianos viejos contestarán, rápida -el día siguiente de la firma- y enérgicamente, un pacto que no compartían con todo un movimiento que acabará en revuelta contra el señor.

Es nuevamente un documento procedente de la casa señorial el que nos pone sobre la pista de los ulteriores acontecimientos ${ }^{61}$. El día 9 de junio se presenta ante el escribano de Lorca, Juan López de Peralta, el conocido cristiano viejo de Vélez Blanco Francisco Barriga para exigirle que notifique a Aparicio López, receptor y testigo de la concordia, un requerimiento en que se hiciese fe pública de cómo estando en casa del alcalde mayor de Lorca los delegados moriscos -los Rapaupe, Almorid, Chelen y Cehel-otorgando una "escriptura contra los vezinos de la dicha villa", él, Francisco Barriga, en nombre de los vecinos de Vélez, les había exhortado a "que no usasen de los poderes que tenían de los vezinos de Vélez"; se quejaba Barriga de que "por muchas cabsas e razones que en el requerimiento van espeçificadas e declaradas, e por muchas vezes que al señor Apariçio López, reçebtor, le he pedido el dicho testimonio no me lo a querido dar, e sy neçesario es de nuevo le requiero..." 62 .

El testimonio precedente nos pone de nuevo ante el problema de las fuentes sesgadas. Según el relator del marqués que narra los acontecimientos previos al pacto y el desarrollo de este mismo, el "bellaco" de Francisco Barriga se había limitado a presentarse en el lugar del pacto para exhortar a grandes voces a los delegados moriscos a que no firmasen lo que no era más que un engaño, cuando lo que verdaderamente hizo Barriga fue presentar un requerimiento por escrito ante los escribanos allí reunidos, en el cual se exponían las razones de su oposición. El receptor Aparicio López, claro partidario de los intereses del marqués, negaría cuanto pudiera, es decir, el

61. ADMS, Leg. 459, Traslado del requerimiento de Barriga.

62. Ibidem. 
fondo de la cuestión, aunque no el hecho de la entrada de Francisco Barriga con un "escripto de requerimiento" que el mismo Barriga leyó ante los reunidos. Es verdad que los allí presentes ignoraron el requerimiento, incluidos los escribanos, y por supuesto los propios moriscos delegados, que lo rechazaron de plano, alegando que "sy él se quería allar que se hallase presente, que ellos venían de buena volunta a hazer la dicha transçion con su señor e no forçados, e asy que de su voluntad lo hazían, y que el dicho Barriga no quiso asystir a la dicha escriptura".

Ni que decir tiene que los escribanos del pacto respondieron con la máxima lealtad y sometimiento al marqués; así, cuando los vecinos de Vélez Blanco eleven su pleito contra don Luis Fajardo a instancias superiores, negarán la existencia del aludido requerimiento de Barriga. Una prueba que el marqués percibía como muy importante en su nuevo pleito.

Puesto que la concordia anulaba los pleitos de los vecinos ante la Chancillería de Granada, el recurso contra aquélla se hizo ante el Consejo Real de Castilla. La única forma posible de anular el pacto era obteniendo nueva sentencia por parte de la instancia judicial suprema. De inmediato el marqués de los Vélez puso en movimiento a sus abogados con claras instrucciones sobre el proceder en este asunto ${ }^{63}$. Dado que trataban de "contradecir" el pacto, el marqués se ocuparía de "contradecir" a los vecinos.

Las instrucciones al solicitador constituyen todo un tratado de las artimañas del marqués de los Vélez para conseguir sus objetivos. En primer lugar, había que obtener una confirmación del rey de la escritura de concordia con los moriscos. Sabedor el marqués del envío por los cristianos viejos de una persona para contradecir la confirmación, su instrucción es bien expresiva: "se ynorará la dicha contradicion y se pidirá la dicha confirmacion Ilanamente, sin hazer minçión de la dicha contradiçión, y en esto se tendrá la mejor orden que posible sea para que la dicha escriptura se confirme sin que la parte contraria tenga sentimiento dello" 64 . El solicitador debería obtener un traslado de la "contradiçión" presentada por los vecinos y alegar que su pacto se había hecho "en concordia de toda la dicha villa" y que tan sólo eran seis las personas que no habían ratificado la escritura del pacto. No se sabe bien en qué forma hacía el marqués la cuenta de los opositores, pero es cierto que los aproximadamente 500 vecinos, entre moriscos y cristianos viejos, que no habían accedido a firmar la concordia -así lo reconoce un testimonio de la propia documentación señorial-, los reducía a seis. Ésta es la cifra de opositores a su concordia que presenta en la alegación ante el Consejo de Castilla.

63. ADMS, Leg. 459. Lo que se a de adevertir al solicitador que el muy exçelente señor marqués de Vélez tiene en corte de su magestad...

64. Ibidem. 
Al categórico argumento de tan menguada oposición, se seguirán otros en que se encomien los grandes beneficios que para la villa se siguen de la concordia, como que los pleitos ocasionan "grandes gastos" a los vecinos, o el más particularmente falaz de que "todo el pueblo, a lo menos la mayor parte $^{65}$, están muy contentos con lo asentado y capitulado en la dicha escriptura de transaçión, y que los dichos capítulos della tocan prinçipalmente a los cristianos nuevos, y con ellos eran los dichos pleytos"66.

Pero al margen de sus argumentos, el marqués conocía perfectamente los fundamentos de una posible invalidación de la concordia por Consejo Real. El principal, el problema de la representación que ostentaban los delegados moriscos firmantes, pues era notorio que además de no representar a la mayoría, habían alcanzado su delegación de una forma harto oscura, suplantando a los legítimamente diputados en primera instancia. De ahí su diligencia para despejar cualquier sombra de duda. De los cuatro delegados nombrados inicialmente, uno, Hernando Rapaupe se integró en la segunda comisión; García Ramí, después de su enérgica oposición, había ratificado explícitamente la escritura -no importan ahora bajo qué presiones-; Hernando Morcel se había apartado discretamente, oportunamente, marchándose a Huéscar para no "hallarse presente"; Francisco Barriga, en fin, que sí estuvo presente el día del acuerdo, pero que se negó a participar en el mismo, seguía de decidido contradictor; sin embargo, de su requerimiento nadie decía saber nada.

En cualquier caso, el problema no se limitó al recurso de los vecinos ante la justicia real. Fue mucho más allá, superando toda posible previsión, hasta la revuelta contra el señor. Por las instrucciones de don Luis Fajardo a su solicitador en la corte sabemos que los cristianos viejos se habían amotinado en la villa de Vélez Blanco contra el abuso que en su apreciación significaba la concordia. Los líderes de la revuelta son conocidos: el más notable, Alonso Rodríguez, el mismo que había sido designado por el marqués como representante suyo, hombre de confianza en la negociación, y acaso el más notable de los forjadores del pacto. El otro cabecilla, un clérigo, beneficiado de Vélez Blanco, Martín de Falces, es un personaje del que la documentación notarial informa de una notable actividad económica en los años previos a la rebelión morisca de 1568 -compra de tierras y animales-, durante los de la guerra misma ${ }^{67}$ y en los posteriores, en que se favoreció del gran botín humano, del mercadeo de los numerosos esclavos moriscos que aportó la gue-

\footnotetext{
65. La cursiva es nuestra.

66. ADMS, Leg. 459.

67. Una amplia descripción de su actividad se encuentra en J.A. TAPIA Garrido, Historia General de Almería..., X, pp. 226-228.
} 
rra de las Alpujarras, muy presente en las tierras del Marquesado de los Vélez ${ }^{68}$.

La revuelta de los cristianos viejos debió producirse en el mes de mayo de 1568, casi un año después de la firma de la concordia. En este sentido los documentos no son precisos, pues tan sólo señalan la fecha del día 3 de mayo sin precisar el año. Es fácil colegir que se trata de 1568: 1567 no puede ser, porque la concordia se firma en junio de ese año; tampoco, 1569, el segundo año de la guerra -que como se sabe había estallado en la Navidad de 1568-, porque don Luis Fajardo se encontraba combatiendo contra los moriscos sublevados en el Reino de Granada, y entre sus acompañantes en campaña estaba el beneficiado Martín de Falces.

El detalle de la revuelta se conoce merced a una cumplida "crónica" elaborada por alguno de los servidores del marqués, tal vez un escribano de Vélez Blanco ${ }^{69}$. Es un relato de los acontecimientos que sucedieron en aquella "asonada, liga e confederación". Un relato que demanda, no obstante, del historiador la ponderación cuidadosa de sus causas y precipitantes.

Los sucesos tienen lugar en la noche del día 3 de mayo, cuando "andava muncha gente de en dos en dos y de quatro en quatro disfraçados por las calles haziendo junta de gentes, atrayéndolos con un tambor y flauta, que andava a manera de asonada, causando muy grande escándalo y alboroto en el pueblo...". Según las informaciones de las justicias del marqués, fueron los eclesiásticos de la villa, junto con varios cristianos viejos, los que iniciaron la revuelta; sin embargo, estas mismas fuentes señalan a dos, los ya citados Rodríguez y Falces, como los verdaderos instigadores. El lugar elegido para la revuelta es la iglesia de Santiago de la villa, en donde están a resguardo de apresamiento por las justicias del señor. Allí se juntan varios clérigos, Martín de Falces, Jorge Merino ${ }^{70}$, Gómez Piñero, Juan López, y muchos cristianos viejos más, entre los cuales se reconocen a Alonso Rodríguez, Juan de Vitoria $^{71}$, Pedro Alfonso, Juan de Barrionuevo y Juan Álvarez. A todos ellos

68. F. AndúfAr CASTILlo, «Entre la 'administración ' y la esclavitud...», pp. 739-750; id., «La continuidad de la guerra...».

69. ADMS, Leg. 459. Relacion de lo que a pasado açerca de la junta que an hecho muchos cristimos viejos a manera de asonada, liga, confederaçion es la siguiente...

70. Jorge Merino, en julio de 1568, se encontraba en la cárcel de Vélez Blanco por orden de un ejecutor del rey. Con gran habilidad logró escapar y refugiarse en la iglesia. Por este hecho su carcelero, Diego de Villaroel, alguacil mayor de Vélez Blanco, pasaría a ocupar su lugar en la prisión por orden del mismo ejecutor (AHPA, Protocolos, 2955, fol. $111 \mathrm{r}$ ).

71. Juan de Vitoria estaba vinculado con Alonso Rodríguez. Como arrendador de las rentas del ganado y de la lana de cristianos nuevos, así como de la renta del queso de los siete novenos de la villa, Juan de Vitoria recibió, el 24 de mayo de 1567, el favor de Alonso Rodríguez y de Juan Bautista de Leizarán, en su calidad de fiadores, para el pago al vicario de la iglesia de la villa, Juan Bautista de Prado, de una suma de 56.768 maravedís que suponían tales rentas en aquel año (AHPA, Protocolos, 2953, fol. 126 v). 
se les acusará para su descalificación pública de haber entrado en la iglesia a tratar su "Iiga y monipodio" con irreverencia hacia el "santísimo sacramento, junto al sagrario paseándose y bueltas las espaldas".

Los amotinados permanecieron reunidos en la iglesia durante hora y media, y al día siguiente, "andavan conbocando y atrayendo gentes, haziendo bolsa común para que cada uno mandase para sus pretensiones dineros y se juntasen la noche siguiente; y assí con mayor alboroto se juntaron en la dicha yglesia a los quatro de mayo en la noche, tocando assí mismo el tambor y flauta por las calles..."72. Según un testigo indirecto de aquellos acontecimientos -pues se "lo habían contado dos de la junta"-, que luego pasaría información al marqués, los revoltosos "se juramentaron que si alguno dellos fuese preso por qualquier causa o delito, procurarían a costa de todos sacarlo de la prisión, y sobre ello yrían a Granada y a corte; e quando no bastase romperían la cárcel para ello"73.

Las causas del motín no ofrecían dudas -al menos para los informadores del marqués-: "para contradezir la transaçión que el conçejo e vezinos desta villa de Vélez el Blanco a hecho con su exçelencia". Un auténtico contrafuero para el poder señorial; no obstante, el marqués se ve frenado en su represión de los instigadores porque algunos de los amotinados cuentan con el amparo del rey, que "no los prendan ni molesten por razón de seguir los dichos pleytos", lo que hace dudar a las justicias del señor. Mientras tanto, los moriscos no sólo se mantenían al margen de la asonada viejo-cristiana, sino que parecían desentenderse de la otra rebelión, la gran rebelión que se estaba fraguando en tierras no muy lejanas del Reino.

Queda dicho que los cabecillas de la revuelta -siempre, según los informantes del marqués- fueron el beneficiado Martín de Falces y Alonso Rodríguez, el otrora "servidor" del marqués. Ambos aparecen como los promotores del motín, por sus "particulares y apasionadas pretensiones", motivaciones que la fuente subraya, y que en la opinión del marqués deslegitiman radicalmente su contestación. Al parecer, Alonso Rodríguez estaba molesto con el marqués porque pretendía que su mujer se sentase en la capilla mayor de la iglesia, donde ninguna otra podía hacerlo, alegando que tenía licencia del obispo para ello, y como el concejo consideró que había otras mujeres de tanta calidad como ella que nunca se sentaron en dicha capilla, el alcalde y los regidores ordenaron quitar el estrado que tenía, mandando pregonar que nadie lo hiciese en aquella capilla. Este hecho-siempre según los informantes del marqués- afrentó mucho a Alonso Rodríguez, quien pensó que detrás de esa maniobra estaba la mano del marqués, por lo

72. ADMS, Leg. 459, Relacion de lo que a pasado....

73. Ibidem. 
que se decidió a promover la revuelta, contradiciendo al señor allá donde era mayormente sensible, la escritura de concordia, que, por cierto, él mismo había promocionado y firmado en su nombre. Por su parte, el beneficiado Martín de Falces se había sumado a la causa porque, al parecer, había solicitado a don Luis Fajardo que le concediese una merced de tierra libre de terrazgo; y la petición le había sido denegada, pues esa carga era irrenunciable para el señor; de ahí su despecho. Sea como fuere, lo cierto fue que tanto Martín de Falces como Alonso Rodríguez estuvieron "ynduziendo a los vezinos para que diesen poder a hazer la dicha contradiçión".

La insistencia de las fuentes señoriales en las motivaciones personales de los cabecillas de la revuelta puede resultar sospechosa, mas carecemos de documento alguno que permita contrastar esa información. Hay, no obstante, un dato que, más allá de una mera coincidencia, podría relacionarse con los acontecimientos de los días 3 y 4 de mayo. Desde la firma de la concordia con los moriscos, el 7 de junio de 1567, el marqués de los Vélez apenas había concedido unas pocas mercedes a sus vasallos para roturar nuevas tierras -aceptar las mercedes suponía acatar la concordia-. Sin embargo, en abril de 1568, los asientos de concesión de nuevas mercedes de tierras se disparan: tan sólo en ese mes, don Luis Fajardo concede 362 fanegas de tierra para ser roturadas $y$, significativamente, entre los destinatarios se encuentran dos de los moriscos firmantes del pacto, Hernando Rapaupe y Rodrigo Cehel, que reciben 30 y 45 fanegas, respectivamente. Cabe pensar que el marqués había iniciado el proceso de recompensa por los favores de la concordia.

El problema se agudiza a lo largo del mes de mayo. El segundo día de la revuelta, el cuatro, los cristianos viejos aprovechan la noche para una nueva sonada. Durante el día, el secretario del marqués, Gaspar Hernández Camacho, ha desarrollado una actividad frenética. Por orden del marqués, escribe y firma la considerable cantidad de 23 mercedes de tierras que se entregan sin excepción a moriscos; suman 915 fanegas, todas ellas en el término de Vélez Blanco ${ }^{74}$. Nótese que esta cifra suponía un poco menos de la mitad de las concedidas durante el año de 1568 en todo el Marquesado y el $70 \%$ de la superficie nuevamente roturada en el término de Vélez Blanco. En un solo día no era posible proceder a tan ingente distribución de tierras $^{75}$;

74. En total se concedieron ese año 2.228 fanegas de tierra. Cf. F. ANDÚJAR CASTILLO y M. BARRIOS AGUILERA, «Los moriscos de los secanos...».

75. Entre los moriscos que se benefician de estas mercedes, figuran nuevamente conocidos personajes. Así, reciben mercedes de tierras, el 4 de mayo de 1568, Hernando Morcel, 30 fanegas -recuérdese que fue el miembro de la primera representación de moriscos que se marchó a Huéscar para "ignorar" la firma de los nuevos diputados-. Figura igualmente Juan Alhariz con 50 fanegas -era hijo del alcalde homónimo de Vélez Rubio que había actuado en la negociación con los moriscos en nombre del marqués-. Varios familiares de Martín Chelen también recibirán el favor del señor. Cf. ADMS, Leg. 481, Libro de mercedes de tierras..., s. fol. 
probablemente, la operación se había preparado con anterioridad, si bien se había consumado al día siguiente del estallido del primer motín de los cristianos viejos.

Si hacemos un seguimiento de las mercedes, observamos que a partir del 4 de mayo quedan paralizadas las concesiones de tierras en Vélez Blanco. Hasta el mes de noviembre de 1568 no vuelve a conceder don Luis Fajardo una nueva merced en esta villa -que hace en la persona de un criado suyo, Bartolomé Maldonado-. Demasiadas coincidencias: es evidente la relación revuelta viejo-cristiana/concesión de mercedes a los moriscos. Da la impresión de que el marqués no había calculado las consecuencias de su decisión de hacer efectiva la concordia, concretada en la concesión de mercedes de tierras a los cristianos nuevos, los firmantes del pacto. Difícilmente los cristianos viejos podían aceptar esa realidad, de ahí el furor de su reacción. El inquilino de la fortaleza-palacio de Vélez Blanco acaso había infravalorado el poder y la fuerza de la oligarquía económica local que se había formado al margen de los cargos en el concejo que él nombraba a su antojo.

El Libro de mercedes conservado entre la documentación señorial es una fuente muy fiable; tanto que incluso descubre el "veneno" documental de los instrumentos preparados por el marqués de los Vélez para su alegación judicial, orientada a reafirmar la validez de la concordia signada con los moriscos. El marqués ocultaba cuidadosamente las motivaciones de los cristianos viejos para su revuelta. Los cristianos viejos no aceptaban la concordia, y sus efectos, esto es, que el favor del señor recayese en los moriscos; mucho menos, que usurpara derechos que no le correspondian sobre los baldíos y montes. Eso explica la clara orientación de la revuelta, una clara reacción antiseñorial, no contra los moriscos. Don Luis Fajardo había convertido a los moriscos en un instrumento a su servicio para restar poder a la oligarquía cristiano-vieja y para aumentar sus derechos señoriales. La tan debatida protección dispensada por "los señores hacia los moriscos" es un hecho cierto en este caso, aunque los moriscos fueron un simple instrumento para lograr objetivos espúreos.

El colorido del relato no debe ocultar la realidad de una historia que se repite. El fuerte enfrentamiento entre don Luis Fajardo y los cristianos viejos se prolongó más allá de la asonada de mayo de 1568. El marqués tomó nota de la contestación de sus vasallos. Redobló sus argucias y renovó sus estrategias de defensa ante la justicia de Granada. El 29 de septiembre de 1568 los ecos de la revuelta aún resuenan. Ese día, un tal Diego de Arenas comparece ante el escribano para otorgar un poder notarial a tres procuradores de Granada. Arenas es un servidor del marqués; el poder es para continuar los pleitos y causas que se siguen contra Alonso Rodríguez, Martín de Falces, Andrés Navarro, Pedro Jiménez, Sebastián de la Iglesia, Ginés Gázquez y Juan Mateo, todos ellos cristianos viejos de Vélez Blanco, "sobre çiertas tierras que los susodichos tienen tomadas e ocupadas al conçejo e veçinos desta 
villa en los términos públicos e concejiles della"76. La escritura no ofrece duda: don Luis Fajardo ha lanzado su ofensiva contra los cabecillas de la revuelta de mayo de 1568 y les acusa precisamente del delito que él mismo está tratando de perpetrar, so capa de derecho: les acusa de ocupar los baldíos que pertenecen al concejo. Es de todo posible que los ahora acusados hubiesen tomado tierras de los términos públicos, pero la gran batalla que se libra durante esos años es justamente el intento del marqués de convertirse en propietario de todas las tierras no cultivadas así como de los montes públicos. El criado del marqués actúa en defensa del concejo, para preservar un bien público, que por otro conducto el marqués está tratando de convertir en un bien particular de su casa.

Don Luis Fajardo muere en su villa de Vélez Blanco el día 5 de julio de $1574^{77}$. A su muerte, siguiendo la tradición heredada de su padre, el marqués lega a su sucesor una extensa nómina de pleitos con diferentes villas de su. señorío en diversas instancias judiciales. En el inventario de los pleitos pendientes de resolución, entre los que predominan los que le enfrentaron con sus poblaciones del Reino de Murcia, todavía figura el pleito por estancos e imposiciones con su villa de Vélez Blanco, lo que demuestra que, pese al empeño de don Luis Fajardo por legitimar la "transaçión", la contradicción no pudo ser silenciada; se demostraba que el problema de la representatividad persistía, y que los que habian quedado fuera de la firma del pacto perseveraron en su rechazo, incluidos los moriscos renuentes. A la altura de 1574, los moriscos de Vélez Blanco ya no andaban por estas tierras, sino por las de Albacete y Cuenca. Los moriscos firmantes y no firmantes de la concordia habían sido deportados, pero el pleito con los cristianos viejos subsistía.

El tercer marqués de los Vélez había de enfrentarse a un enemigo formidable, su señor natural, Felipe II, que aprovecharía la repoblación de las tierras dejadas por los moriscos expulsos para restar poder al Fajardo. Se habían invertido las tornas: la conflictividad tomaba una insospechada nueva dirección que liquidaba de hecho el pleito interminable entre señor y vasallos, para escribir nuevos capítulos, en que la oposición sería señor-Estado. Pero ésta es una historia bien distinta, aunque no menos apasionante ${ }^{78}$.

76. AHPA, Protocolos, 2955, fol. $120 \mathrm{r}$.

77. ADMS, Leg. 1126.

78. Vid. F. AndúJAR CASTILlo, «Señores y Estado en la repoblación de Felipe II...». El segundo marqués de los Vélez, don Luis Fajardo, hubo de enfrentarse, en sus últimos años de vida, duramente, y sin éxito, al poder estatal personificado en la figura del recio alcalde de corte licenciado Bonifaz, representante prototípico de una concepción nada complaciente con las apetencias señoriales, que tuvo en la repoblación filipina un campo abonado de práctica. 


\section{RESUMEN}

Durante el siglo XVI, los titulares de los señoríos incrementaron sus derechos jurisdiccionales utilizando prácticas de todo orden, entre las cuales una de las más extendidas fue la usurpación de derechos a los vasallos. En este trabajo -cruzando fuentes documentales muy diversas y procedentes de todas las partes implicadas- se desentrañan los mecanismos utilizados en el inequívoco proceso de usurpación que tuvo lugar en el marquesado de los Vélez en los años inmediatos a la rebelión de los moriscos. El señor pactó con una parte de la comunidad morisca de Vélez Blanco, urdiendo una compleja trama para apropiarse una serie de derechos que reclamaban tanto los moriscos mismos como los cristianos viejos. Como consecuencia del "pacto", la oligarquía local cristiano-vieja promovió un motín contra las pretensiones del señor. Esto sucedía allá por 1568, el mismo año de la rebelión de los moriscos.

\section{ABSTRACT}

During the 16th century, the titulars of manors increased their jurisdiction rights using all kinds of methods, one of the most extended was the usurpation of rights to vassals. In this study, crossing different documental sources proceeding from all the parts implicated in the actions used in this unequivocal process of usurpation in Velez Marquis in the inmediate years to the Moorish revolt are discovered. The noble agreeded with part of Moorish community from Vélez Blanco, organizing a complex web in order to appropriate some rights that were demanded by the Moorish and the old Christian. As a result of this "agreement" the local old Christian oligarchy instigated riots against the noble's objectives. These events were happening in 1568, the same year of the Moorish rebellion. 